PNL-3962

UC-60

Final Report

\title{
Analysis of the Effects of Integrating Wind Turbines into a Conventional Utility: A Case Study
}

M. K. Goldenblatt

H. L. Wegley

A. H. Miller

August 1982

Prepared for

Pacific Northwest Laboratory

under Agreement B-93474-A-L of

Contract DE-AC06-76RLO 1830

for the U.S. Department of Energy

Pacific Northwest Laboratory

Operated for the U.S. Department of Energy

by Battelle Memorial Institute 


\title{
DISCLAIMER
}

This report was prepared as an account of work sponsored by an agency of the United States Government. Neither the United States Government nor any agency thereof, nor any of their employees, makes any warranty, express or implied, or assumes any legal liability or responsibility for the accuracy, completeness, or usefulness of any information, apparatus, product, or process disclosed, or represents that its use would not infringe privately owned rights. Reference herein to any specific commercial product, process, or service by trade name, trademark, manufacturer, or otherwise, does not necessarily constitute or imply its endorsement, recommendation, or favoring by the United States Government or any agency thereof. The views and opinions of authors expressed herein do not necessarily state or reflect those of the United States Government or any agency thereof.

\author{
PACIFIC NORTHWEST LABORATORY \\ operated by \\ BATTELLE \\ for the \\ UNITED STATES DEPARTMENT OF ENERGY \\ under Contract DE-AC06-76RLO 1830
}

\begin{tabular}{|c|c|}
\hline \multicolumn{2}{|c|}{ Printed in the United States of America } \\
\hline \multicolumn{2}{|c|}{ Available from } \\
\hline \multicolumn{2}{|c|}{ National Technical Information Service } \\
\hline \multicolumn{2}{|c|}{ United States Department of Commerce } \\
\hline \multicolumn{2}{|c|}{5285 Port Royal Road } \\
\hline \multicolumn{2}{|c|}{ Springfield, Virginia 22151} \\
\hline \multirow{2}{*}{\multicolumn{2}{|c|}{$\begin{array}{l}\text { NTIS Price Codes } \\
\text { Microfiche A01 }\end{array}$}} \\
\hline & \\
\hline \multicolumn{2}{|c|}{ Printed Copy } \\
\hline & Price \\
\hline Pages & Codes \\
\hline $001-025$ & $\mathrm{~A} 02$ \\
\hline $026-050$ & $\mathrm{~A} 03$ \\
\hline $051-075$ & $\mathrm{~A} 04$ \\
\hline $076-100$ & A05 \\
\hline $101-125$ & $\mathrm{~A} 06$ \\
\hline $126-150$ & $\mathrm{~A} 07$ \\
\hline $151-175$ & A08 \\
\hline $176-200$ & $\mathrm{~A} 09$ \\
\hline $201-225$ & A010 \\
\hline $226-250$ & A011 \\
\hline $251-275$ & A012 \\
\hline 276-300 & A013 \\
\hline
\end{tabular}


ANALYSIS OF THE EFFECTS OF

INTEGRATING WIND TURBINES INTO A

CONVENTIONAL UTILITY: A CASE STUDY

\section{Final Report}

M. K. Goldenblatt

H. L. Wegley(a)

A. H. Miller (a)

JBF Scientific Corporation

2 Jewel Drive

Wilmington, Massachusetts 01887

August 1982

Prepared for Pacific Northwest Laboratory under Agreement B-93474-A-L of Contract DE-AC06-76RLO 1830 for the U. S. Department of Energy

Pacific Northwest Laboratory Richland, Washington 99352

(a) Pacific Northwest Laboratory 



\section{EXECUTIVE SUMMARY}

This report documents three aspects of the integration of wind turbine generation (WTG) into a selected utility generating system, the Los Angeles Department of water and Power (LADWP). The objectives of the study were to examine the sensitivity of the economic impact of WTG to wind speed sampling frequency, wind turbine performance model and wind speed forecasting accuracy. A11 work was performed by JBF Scientific Corporation using wind data and the time-dependent model code supplied by Pacific Northwest Laboratory (PNL) and the static models and utility production cost models supplied by JBF.

The intital phase of the study consisted of calculating the expected output of the Boeing MOD-2 wind turbine using various turbine performance models driven by wind data representing different sampling frequencies. The basic wind data set used consisted of instantaneous values of wind speed and direction recorded at 2-min intervals. These data were measured at the DOE meteorological tower in San Gorgonio Pass, California during calendar year 1979. Four different simulation methods were used with the wind data to estimate MOD-2 performance:

1. A time-dependent performance simulation of machine operation that adapts the MOD-2 control logic for startup, shutdown and yawing for use with the 2-min wind data to calculate 2-min power output. Each hour the 2-min power output is integrated to obtain hourly power output. This represents a new method of performance evaluations.

2. An integrated hourly performance model that estimates machine output every 2 min using the wind speed versus power output curve (performance envelope) for the MOD-2. Hourly power output was obtained by integrating 2-min power output over each hour. This method is similar to the performance evaluation being done by PNL for NASA at four DOE MOD-OA sites.

3. An hourly sampled wind speed performance model that uses the last 2-min wind speed sample taken every hour, in conjunction with the performance envelope, to estimate hourly power output. Method 3 is similar to the use of National Weather Service or SOLMET data in estimating wind turbine performance. 
4. An hourly averaged wind speed performance model that uses the 1-hr average of the 2-min wind speeds and the performance envelope for the MOD-2 to estimate hourly machine output. This approach is similar to the way that $D O E$ candidate sites have been evaluated for site selection in the past.

The hourly MOD-2 outputs defined by the four techniques were used as load modifiers in defining the net load that must be serviced by the conventional utility generating sources. On this study net loads were calculated for the 1995 Los Angeles Department of Water and Power (LADWP) generating system assuming a WTG penetration equal to $10 \%$ of the anticipated peak load. These loads were then supplied to a production cost simulation to estimate LADWP's 1995 annual cost of generation. The results were then used in establishing the sensitivity of LADWP's annual production costs and WTG value to the particular technique used in calculating hourly WTG.

The second phase of the study consisted of examining the impact wind forecasting accuracy would have on LADWP operation and costs. The objective of this phase was to establish the sensitivity of LADWP production costs to wind speed forecasting accuracy in an effort to define realistic goals for wind speed forecasters.

\section{SUMMARY RESULTS}

The following results were obtained from the analysis performed on this study. Caution must be exercised in generalizing these results since they were obtained by analyzing a single utility under very specific assumptions.

- Modeling machine output with a time-dependent simulation and using 2-min wind speed data does appreciably change the MOD-2 capacity factor, production cost savings, and life-cycle savings from those calculated using any one of the three static performance models. Using this simulation decreased MOD-2 annual power output by approximately $13 \%$. This resulted from a combination of increased machine downtime and a decrease in the time the WTG is computed to be operating at rated capacity. 
- Using three different non-time-dependent methods for calculating hourly WTG performance resulted in less than a $3 \%$ difference in the calculated MOD-2 capacity factor. Similarly, WTG life-cycle value calculated also varied by less than $3 \%$ regardless of the non-time-dependent model used.

- Averaging the 2-min wind speeds each hour does not appreciably (1ess than $3 \%$ ) change MOD-2 capacity factor, single-year production cost savings, or life-cycle value from that calculated using wind speed samples taken once every hour (method 3) when WTG power is calculated using a performance envelope.

- The ability of LADWP to forecast wind speeds with state-of-the-art accuracy may increase the production cost savings from WTG by nearly $20 \%$ annual1y.

- The ability of LADWP to accurately forecast wind speeds (wind turbine array power) can decrease its dependency on oil-fired generation. 


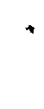




\section{CONTENTS}

Page

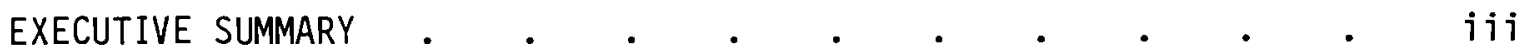

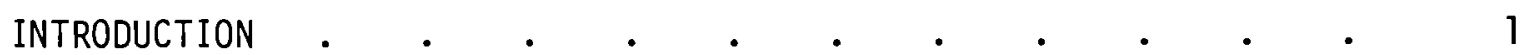

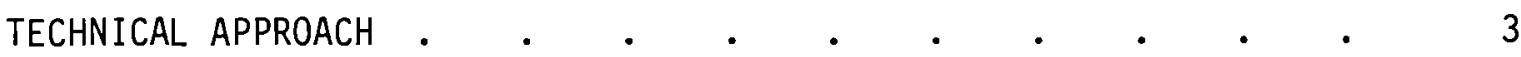

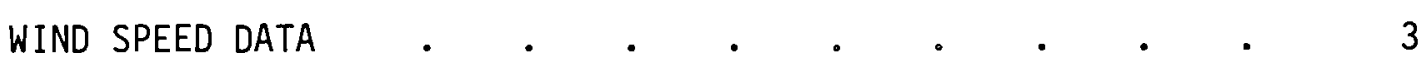

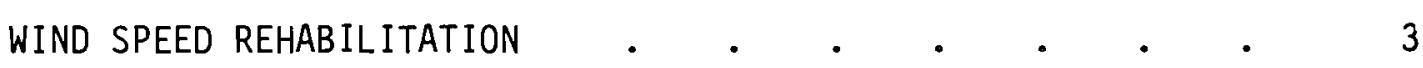

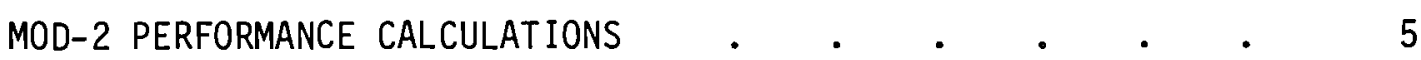

UTILITY DESCRIPTION •

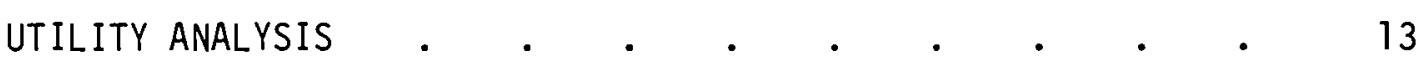

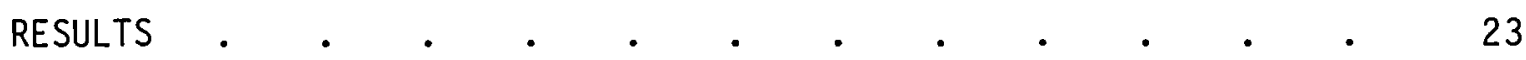

EFFECT OF WIND TURBINE MODELING ON LADWP PRODUCTION

SENSITIVITY OF LADWP PRODUCTION COSTS TO WIND

FORECASTING $. \quad . \quad . \quad . \quad . \quad . \quad . \quad . \quad . \quad . \quad 25$

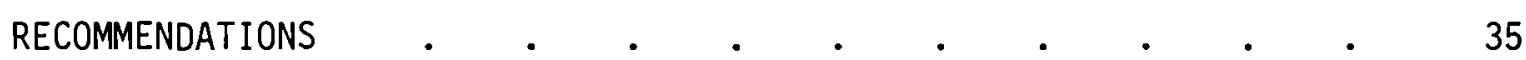

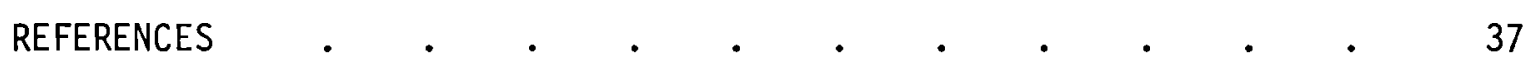

APPENDIX A - REHABILITATION OF SAN GORGONIO WIND SPEEDS .

APPENDIX B - AIR DENSITY CORRECTION $\quad$ - . . . . . . . . B

APPENDIX C - UTILITY OPERATING PROCEDURES . . . . • . . C C

APPENDIX D - LADWP LOADS . . . . . . . . . . . . D-1 


\section{LIST OF FIGURES}

Page

1. San Gorgonio Observed Hourly Wind Speeds at $150 \mathrm{Ft}$ - July

2. San Gorgonio Observed Hourly Wind Speeds at $150 \mathrm{Ft}$ - October

3. Wind Speed Rehabilitation Processes . . . . . . 5

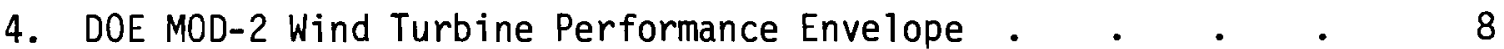

5. Monthly Capacity Factors for MOD-2 Output . $\quad$. $\quad$ - $\quad 12$

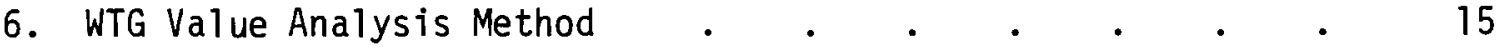

7. Wind Speed Forecasting Impact Analysis Method . $\quad$. 18

8. Methodology for Calculating Wind Induced Operating 22

9. Production Cost Sensitivity to Standard Deviation in Wind Speed Prediction . . . . . . . . 30

A-1. Wind Speed Rehabilitation Methodology . . . . . . A $A-2$

A-2. Wind Speed Extrapolation Factors (alphas) 1979 San Gorgonio Pass, CA, Data . . . . . . . A-4

A-3. San Gorgonio Observed and Rehabilitated Hourly
Wind Speeds at $150 \mathrm{ft}$ - August . . . . . . A-5

A-4. Monthly Wind Pattern 1979 San Gorgonio Pass Data at $200 \mathrm{ft}$. . . . . . . . . A A-6

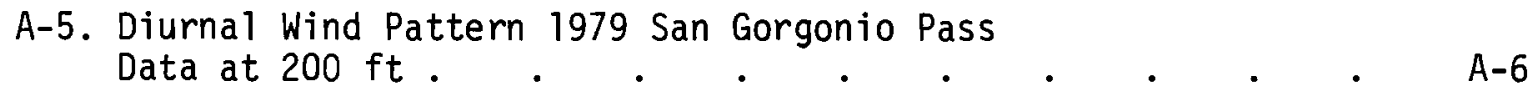

A-6. Wind Duration Curve 1979 San Gorgonio Wind Data . . - A-7

D-1. 1995 Estimated LADWP Hourly Load Profile . . . . . D-1

D-2. 1995 Estimated Average Daily Load Profile . . . . . D-2 


\section{$\underline{\text { LIST OF TABLES }}$}

Page

1. Average Hourly Performance Results . $\quad$ • $\quad$ • $\quad$. $\quad$ • $\quad$. 9

2. Frequency Distribution of MOD-2 Power Output . . . . . 9

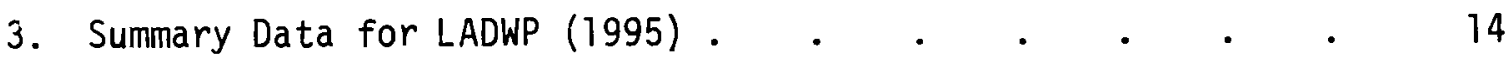

4. LADWP Financial Parameters . $\quad . \quad$. $\quad . \quad$. $\quad . \quad$. 14

5. Effect of MOD-2 Performance on Production Costs and Reliability, Projected 1995 LADWP System . . . . 24

6. Incremental Savings and Fuel Displacement Projected

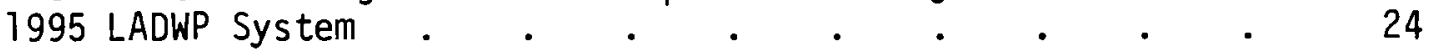

7. Effect of MOD-2 Performance Simulation of MOD-2 Value . $\quad 26$

8. Impact of 0 and $100 \%$ Accuracy in Wind Speed Forecasting on LADWP 1995 Production Costs for the First Week in

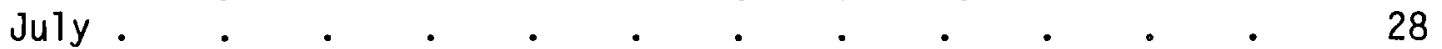

9. Impact of 0 and $100 \%$ Accuracy in Wind Speed Forecasting on LADWP 1995 Production Costs for the First Week in October. . $. \quad . \quad . \quad . \quad . \quad . \quad . \quad$.

10. Examples of Maximum Potential Benefit From Accurate Wind Speed Forecasting . . . . . . . . . 32

$\mathrm{B}-1$. Wind Power Calculations With Density Corrections . . . B $\mathrm{B}-2$ 


\section{INTRODUCT ION}

This report analyzes three aspects of the integration of wind turbine generation (WTG) into a selected utility's generating system. The three objectives of the study were to examine the impact on a utility incorporating wind turbine generation (WTG) to wind speed sampling frequency, wind turbine performance model and wind speed forecasting accuracy. The utility analyzed in the study was the Los Angeles Department of Water and Power (LADWP) and the wind turbine assumed was the MOD-2. It should be noted that in assuming these objectives many of the variables involving costs are forecasts. Therefore one should not assume any of the calculated values or savings are absolute but rather relative within the work reported. 
.

$\checkmark$ 


\section{TECHNICAL APPROACH}

This section presents the approach used in examining the sensitivity of the economic value of wind turbine generation to wind speed sampling frequency and wind turbine modeling technique. It also presents the approach used in examining the impact of wind forecasting accuracy on utility operation and production costs.

\section{WIND SPEED DATA}

To accomplish the objectives of this study, PNL supplied wind speed and direction data recorded at subhourly intervals. The particular data used in this study were recorded in 1979 from the DOE sponsored meteorological tower located near San Gorgonio Pass, California. The sample frequency for this data was one instantaneous observation every 2 min; over a quarter of a million wind samples were used in this study. Excerpts of the data, recorded in July and October of 1979, are presented in Figures 1 and 2, respectively. An examination of the data revealed that approximately $12 \%$ of the wind speed observations were missing due to problems with the data collection equipment. Most of the missing observations (approximately 70\%) occurred in two periods: 10 days in June and 16 days in early August. The remaining missing data occurred scattered throughout the remainder of the year. A rehabilitation process developed by JBF was employed in order to construct a complete year's worth of wind speed data.

\section{WIND SPEED REHABILITATION}

The 2-min San Gorgonio wind speed data were available for two elevations: $9.1 \mathrm{~m}(30 \mathrm{ft})$ and $45.7 \mathrm{~m}(150 \mathrm{ft})$. Since the nacelle of the MOD-2 is at $200 \mathrm{ft}$, it was necessary to extrapolate the available wind speed data to reflect winds at the hub height. A flow diagram of the methods employed in rehabilitating the wind speed data is shown in Figure 3 . The major functions of the rehabilitation process are to: 1) fill in missing observations and 2) to extrapolate wind speed data from measured levels to hub height. In 


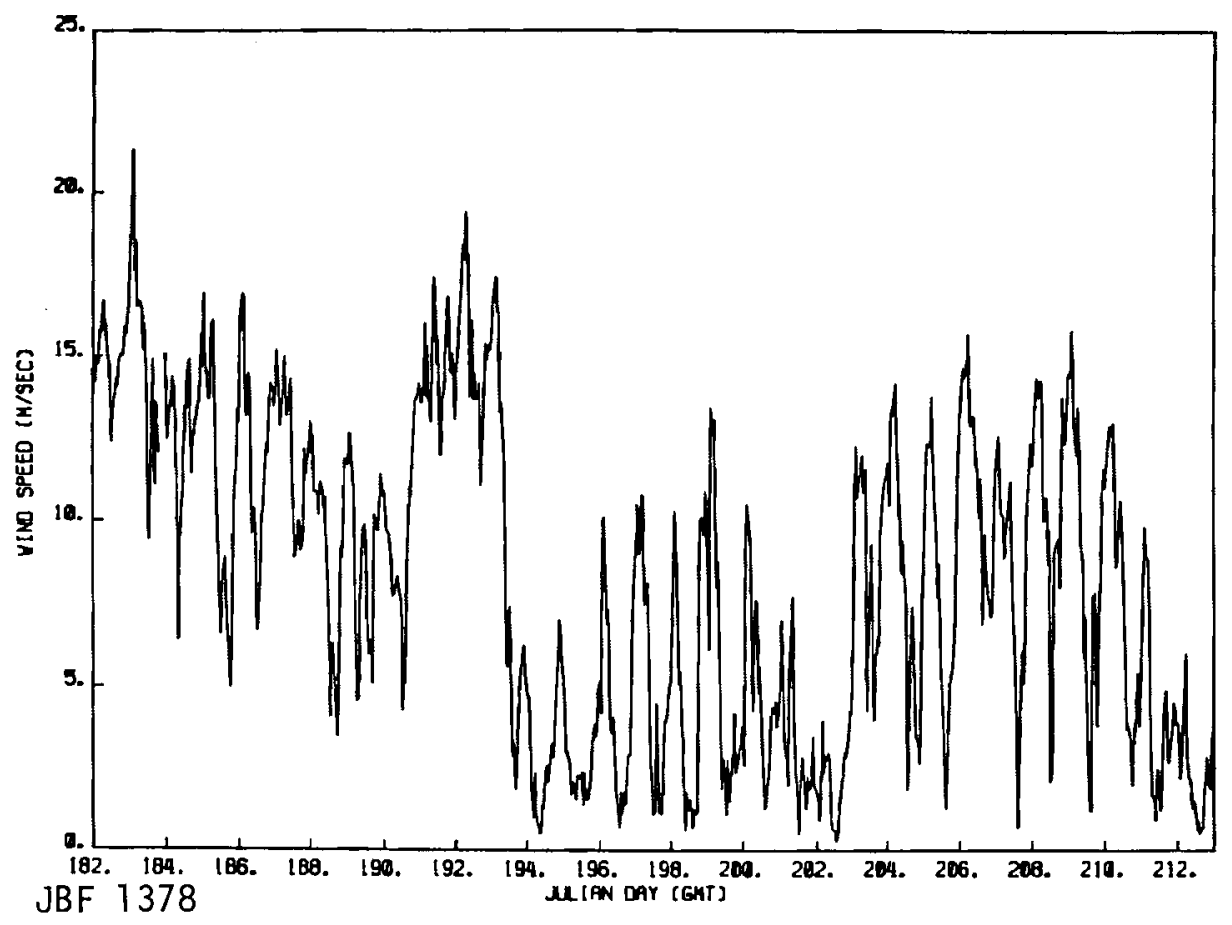

FIGURE 1. San Gorgonio Observed Hourly Wind Speeds at $150 \mathrm{Ft}$ - July

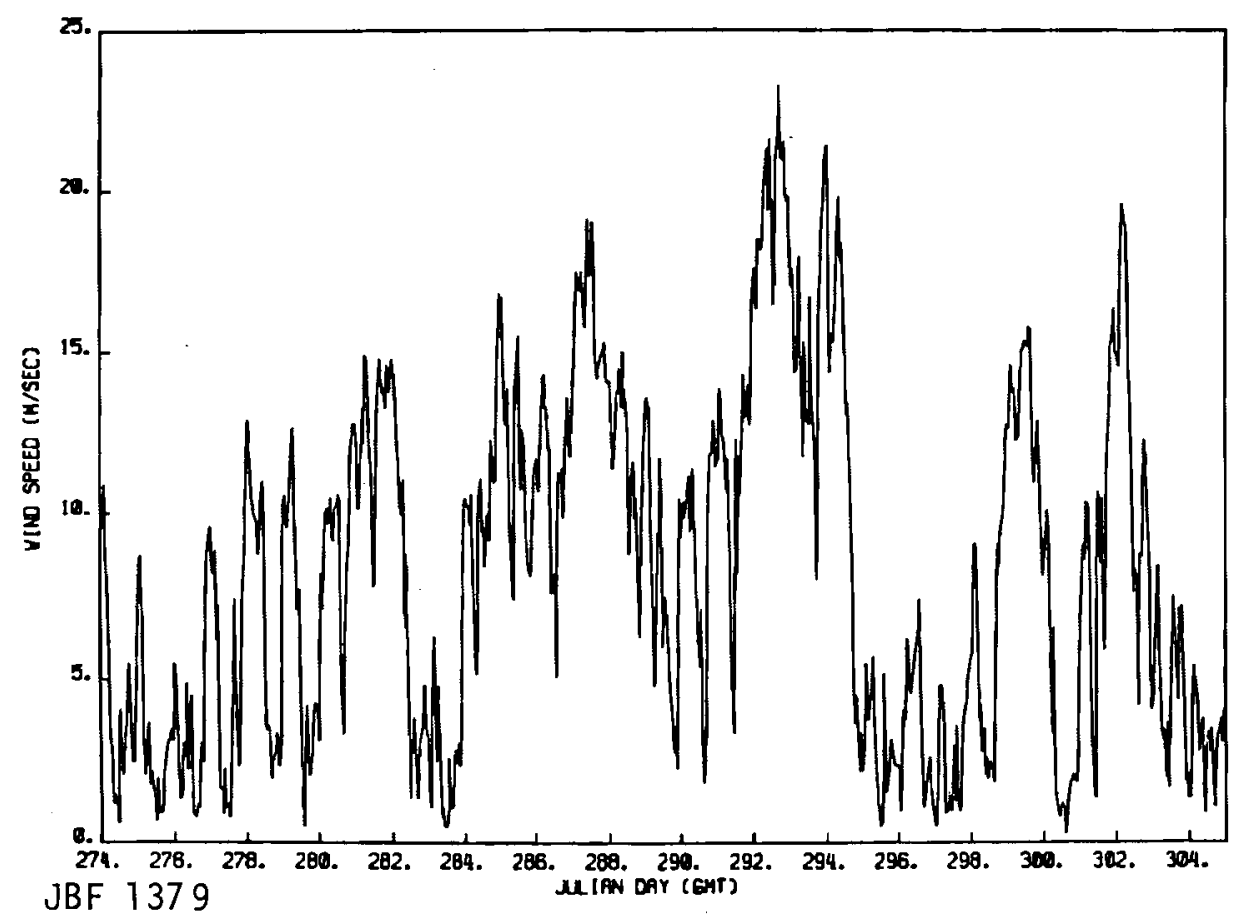

FIGURE 2. San Gorgonio Observed Hourly Wind Speeds at $150 \mathrm{Ft}$ - October 


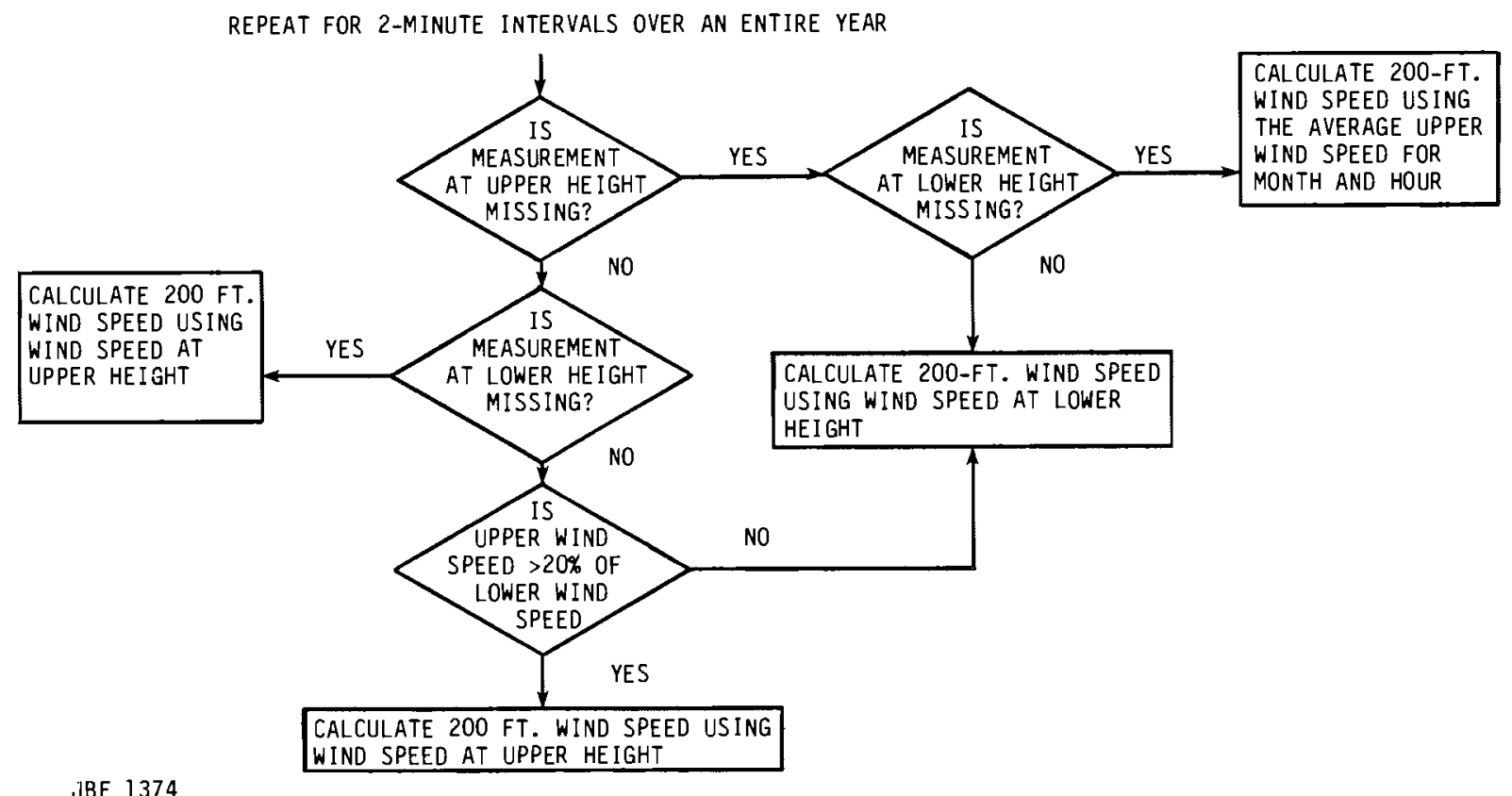

FIGURE 3. Wind Speed Rehabilitation Processes

addition, anomalous data, represented by apparent inconsistencies between measurements at the upper and lower heights, were identified and replaced. A detailed discussion of the process used to construct the full data set is presented in Appendix A.

\section{MOD-2 PERFORMANCE CALCULATIONS}

The performance simulation methods listed below were used with various subsets of the rehabilitated San Gorgonio Pass wind data to determine hourly expected MOD-2 power output:

1. A time-dependent performance simulation of machine operation that adapts the MOD-2 control logic for startup, shutdown and yawing for use with the 2-min wind data to calculate 2-min power output. Each hour the 2-min power output is integrated to obtain hourly power output. This represents a new method of performance evaluation (Miller 1980). 
2. A static integrated hourly performance model that estimates machine output every 2 min using the wind speed versus power output curve (performance envelope) for the MOD-2. Hourly power output was obtained by integrating 2-min power output over each hour. This method is similar to the performance evaluation being done by PNL for NASA at four DOE MOD-OA sites.

3. A static hourly sampled wind speed performance model that uses the last 2-min wind speed sample taken every hour, in conjunction with the performance envelope, to estimate hourly power output. Method 3 is similar to the use of National Weather Service or SOLMET data in estimating wind turbine energy production.

4. A static hourly averaged wind speed performance model that uses the 1-hr average of the 2-min wind speeds and the performance envelope for the MOD-2 to estimate hourly machine output. This approach is similar to the way that DOE candidate sites have been evaluated for site selection in the past.

In the time-dependent performance simulation, features of the MOD-2 control logic were obtained from Boeing engineers and then adapted (as described in the following paragraph) for use with the 2-min wind data. Under certain conditions the MOD-2 control logic calls for wind speed averages of less than 2 min to test for shutdown or yawing conditions. Due to the time constant of the data system used at the candidate site each wind speed measurement represents approximately a 0.1 to $0.5 \mathrm{sec}$ average. Consequently, it was necessary to approximate the MOD-2 averaging intervals, but, in each case the timedependent model was constructed to provide as realistic a simulation as possible with the available 2-min wind data.

The dynamic yawing features of the machine are also simulated, and cosine losses due to rotor yaw error computed. To test for startup conditions, time intervals are selected over which wind speeds are averaged. These time intervals decrease with increasing wind speed. If the first sample is around $6.2 \mathrm{~m} / \mathrm{s}(14 \mathrm{mph})$, the time interval is $10 \mathrm{~min}$. The interval varies from 
$10 \mathrm{~min}$ for low wind conditions to $2 \mathrm{~min}$ for wind speeds around $26 \mathrm{~m} / \mathrm{s}$ (45 mph). For startup to be initiated all wind speeds in the time interval must be greater than $5.8 \mathrm{~m} / \mathrm{s}(13 \mathrm{mph})$ and the average wind speed must exceed $6.2 \mathrm{~m} / \mathrm{s}$ (14 mph). Also, no individual wind speed sample can be greater than $20.1 \mathrm{~m} / \mathrm{s}$ $(45.0 \mathrm{mph})$. These criteria are maintained through the startup process, which involves starting the pumps and yawing the wind turbine into the wind (it can shift $30^{\circ}$ in $2 \mathrm{~min}$ ). When the wind turbine has been yawed, the rotor must be brought up to synchronous speed. This requires 10 min if the wind speeds are around cut-in, and 5 min if wind speed is between rated and cut-out (program uses $6 \mathrm{~min})$. During this rotor acceleration or while the generator is producing, the machine will shut down if any individual 2-min wind speed is below $6.0 \mathrm{~m} / \mathrm{s}$ $(13.5 \mathrm{mph})$ or above $20.1 \mathrm{~m} / \mathrm{s}(45.0 \mathrm{mph})$. The wind speed data input to the model is modified for site specific air density. A description of the method used in this study is given in Appendix B. When the generator shuts down, the tests for startup conditions are reinitiated.

The static performance model uses the MOD-2 power versus wind speed performance envelope shown in Figure 4. The major differences among the three performance simulation methods that use this model are in the manner the 2-min wind speed samples are used in calculating average power output for each hour. In method 2, WTG power is calculated for each of thirty 2-min samples and then the thirty power results are integrated to get the hourly power output. In method 3, the hourly wind speed is represented by one 2-min sample and WTG power is calculated from this. In method 4 the 2-min wind speed samples are averaged every hour and the hourly average wind speed is used in the calculation of WTG power. The hourly power values may differ significantly for the three methods. However, the annual power results may be similar since the methods vary only in sampling rate and since the results for both methods are derived from a large number of samples $(262,800$ in methods 2 and 4, and 8,760 in method 3 ).

The curve identifying the performance of the MOD-2 wind machine as a function of wind speed is shown in Figure 4. The parameters used in defining the MOD-2 performance limits were: 


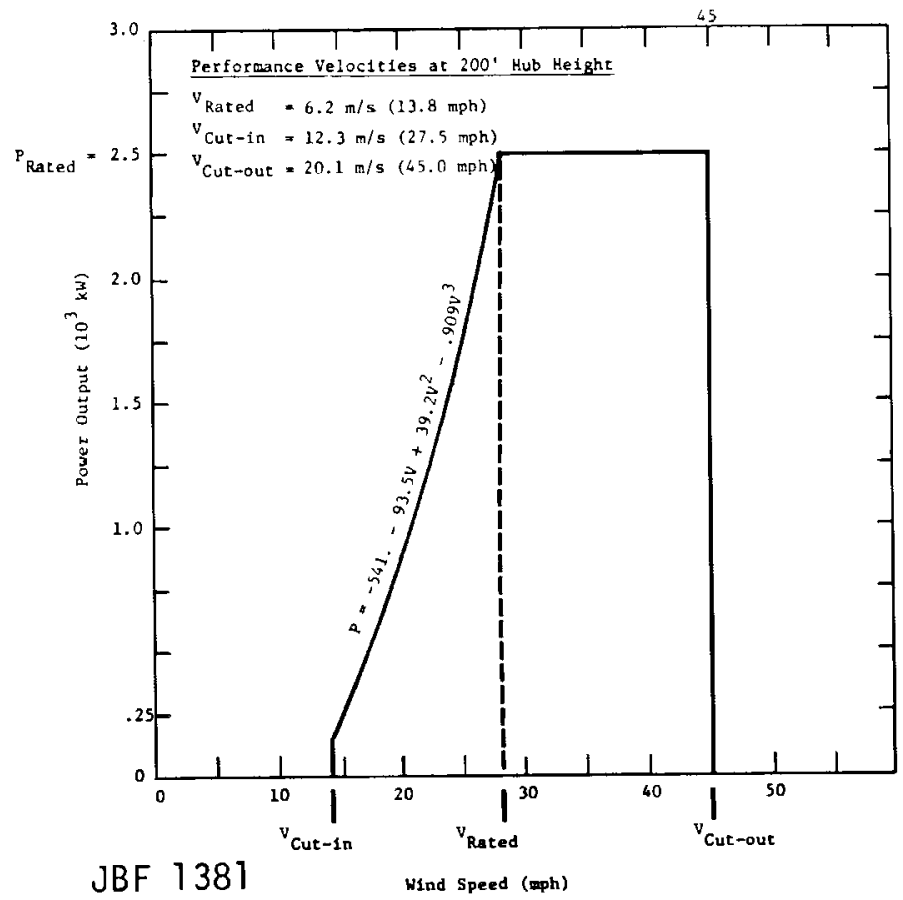

FIGURE 4. DOE MOD-2 Wind Turbine Performance Envelope
Cut-In Speed:
Rated Speed:
$6.2 \mathrm{~m} / \mathrm{s}(14 \mathrm{mph})$
Cut-Out Speed:
$12.3 \mathrm{~m} / \mathrm{s}(27.5 \mathrm{mph})$
$20.1 \mathrm{~m} / \mathrm{s}(45.0 \mathrm{mph})$

The wind speed to power relationship between cut-in and rated wind speeds used was:

$$
P=-541.0-93.5 V+39.2 V^{2}-0.909 V^{3}
$$

where $P=M O D-2$ power output, $\mathrm{kW}$

$V=$ Wind speed, $\mathrm{m} / \mathrm{sec}$.

This relationship was derived by fitting a third degree polynomial to the MOD-2 performance data provided by Boeing and was provided in the timedependent mode 1 code.

Density corrections for elevation were also employed in modeling MOD-2 performance (see Appendix B). Tables 1 and 2 summarize the performance results 
TABLE 1. Average Hourly Performance Results (1979 San Gorgonio Data)

\begin{tabular}{|c|c|c|c|c|}
\hline & $\begin{array}{c}\text { Time- } \\
\text { Dependent } \\
\text { Performance } \\
\text { Simulation } \\
\end{array}$ & $\begin{array}{c}\text { Integrated } \\
\text { Hourly } \\
\text { Performance } \\
\text { Model } \\
\end{array}$ & \begin{tabular}{c}
\multicolumn{1}{c}{ Hourly } \\
Sampled \\
Wind Speed \\
Performance \\
Model \\
\end{tabular} & $\begin{array}{c}\text { Hourly } \\
\text { Averaged } \\
\text { Wind Speed } \\
\text { Performance } \\
\text { Model } \\
\end{array}$ \\
\hline $\begin{array}{l}\text { Annual Capacity } \\
\text { Factor }\end{array}$ & 0.312 & 0.356 & 0.355 & 0.364 \\
\hline $\begin{array}{l}\text { Hours of Down- } \\
\text { time (Power }=0)\end{array}$ & 4201 & 2923 & 4193 & 4209 \\
\hline $\begin{array}{l}\text { Hours of Rated } \\
\text { Power }\end{array}$ & 165 & 183 & 1676 & 1764 \\
\hline $\begin{array}{l}\text { Average Power } \\
\text { Output, }(\mathrm{kW})\end{array}$ & 780 & 894 & 887 & 910 \\
\hline \multicolumn{5}{|c|}{ Annual Average Wind Speed $=7.7 \mathrm{~m} / \mathrm{s}(17.2 \mathrm{mph})$} \\
\hline \multicolumn{5}{|c|}{$\begin{array}{l}\text { Annual Average Wind Speed }=7.5 \mathrm{~m} / \mathrm{s}(16.8 \mathrm{mph}) \\
\text { After Density Correction }\end{array}$} \\
\hline \multicolumn{5}{|c|}{ Station Elevation $=457 \mathrm{~m}$ above MSL } \\
\hline
\end{tabular}

TABLE 2. Frequency Distribution of MOD-2 Power Output (1979 San Gorgonio Data Percent Distributions)

\begin{tabular}{|c|c|c|c|c|}
\hline $\begin{array}{c}\text { Average } \\
\text { Hourly } \\
\text { Power Output } \\
(\mathrm{kW}) \\
\end{array}$ & \begin{tabular}{c}
\multicolumn{1}{c}{ Time- } \\
Dependent \\
Performance \\
Simulation \\
\end{tabular} & $\begin{array}{c}\text { Integrated } \\
\text { Hourly } \\
\text { Performance } \\
\text { Model } \\
\end{array}$ & $\begin{array}{c}\text { Hourly } \\
\text { Sampled } \\
\text { Wind Speed } \\
\text { Performance } \\
\text { Model } \\
\end{array}$ & $\begin{array}{c}\text { Hourly } \\
\text { Averaged } \\
\text { Wind Speed } \\
\text { Performance } \\
\text { Model } \\
\end{array}$ \\
\hline 0 & 48.0 & 33.4 & 47.9 & 48.1 \\
\hline $1-499$ & 8.6 & 17.7 & 5.2 & 4.8 \\
\hline 500-999 & 7.5 & 8.5 & 8.4 & 7.3 \\
\hline $1000-1400$ & 8.0 & 8.8 & 7.7 & 7.7 \\
\hline $1500-1999$ & 8.3 & 8.2 & 6.2 & 5.9 \\
\hline $2000-2499$ & 17.8 & 21.4 & 5.4 & 6.1 \\
\hline 2500 & 1.9 & 2.1 & 19.1 & 20.1 \\
\hline
\end{tabular}


for the four performance simulation methods analyzed. The annual capacity factor of the wind turbine when simulated using the time dependent performance simulation is 0.312 , or 12 to $14 \%$ less than the capacity factors calculated using the static performance models. The reduction in annual power output is due to the startup process and losses due to yaw error. Cosine losses (yaw error) typically account for $5-7 \%$ of the difference.

of the four performance simulations used methods 1 and 2 are similar in that they require that MOD-2 power output be calculated every $2 \mathrm{~min}$. Methods 3 and 4 are similar in that speed, thus power, is assumed constant over each hour. One obvious consequence of this is depicted in Tables 1 and 2 . Methods 1 and 2 introduce more variation into the power output calculations resulting in far less hours of rated power.

For wind speeds below its cut-in wind speed the MOD-2 does not produce any power. For wind speeds above its rated wind speed the output of the MOD-2 as a function of wind speed is a constant $2.5 \mathrm{MW}$. Between cut-in and rated wind speeds the output of the machine is dependent upon the available wind speed resource with power output being nearly a quadratic function of wind speed. As a result of this nonlinear relationship between MOD-2 power produced and wind speed, using an average hourly wind speed to calculate the machine's hourly performance does not yield the same results as using available 2-min wind speed data and averaging hourly the calculated machine output. For average hourly wind speeds that are calculated to be either slightly below cut-in or above rated wind speeds, this effect is more pronounced. Two-minute wind speeds above the MOD-2's cut-in wind speed that were used in calculating an average hourly wind speed below cut-in are in effect ignored in calculating the machine's output for the hour. Yet in reality, the machine could have produced power for subhourly periods that contained an adequate wind resource. A similar effect occurs for calculated average hourly wind speeds that are slightly above rated wind speed. In this case the reduction in calculated MOD-2 output due to the occurrence of subhourly wind speeds that are below the MOD-2's rated wind speed is not accounted for in calculating machine performance. 
Conversely, it is difficult for the integrated hourly performance model to calculate the MOD-2 as being either "down" or at rated power for an entire hour since it only takes one 2-min wind speed that is above cut-in or below rated wind speeds to show the machine either having power or operating at less than rated for the given hour.

The consequences of these effects can be seen in Table 1, which presents the hours the MOD-2 was both in a down condition and at rated power for the four simulation methods. Simulating the performance of the MOD-2 using the hourly sampled and hourly averaged wind speed performance models resulted in the MOD-2 being calculated to be down (zero output) and at rated power over 4100 and $1600 \mathrm{hr}$, respectively. This compares to the machine being calculated to be down slightly under $3000 \mathrm{hr}$ and at rated power slightly under $200 \mathrm{hr}$ for the integrated hourly performance model.

It must be noted that the time-dependent performance simulation includes startup lags which may take as long as 22 min under worst-case conditions. As a result, using this method to calculate machine power results in an increase in the amount of time the machine is calculated to be down (as compared to using the integrated hourly performance model, which is the other simulation method that calculates power every $2 \mathrm{~min}$ ). However, the amount of time the machine is calculated to be at rated power is very similar to that calculated using the integrated hourly performance model: less than $200 \mathrm{hr}$.

It is interesting to note in Table 1 that the three static methods (2 through 4) show nearly identical capacity factors; but, method 2 produces a much different time running at rated and downtime. This is explained in Table 2 by the distribution of power between cut-in and rated. In this region, method 2 computes $21.4 \%$ of $i$ ts power output as lying between 2 and $2.49 \mathrm{MW}$, which is nearly at MOD-2 rated power (2.5 MW) and is sufficient to boost the capacity factor up to that of methods 3 an 4 . However, the $17.8 \%$ for the time-dependent model (in the $2.0-2.49 \mathrm{MW}$ interval) reduces the capacity factor for that method below methods 2,3 and 4 . 
To observe if the distribution of the power calculated for the three static techniques is similar, at least on a monthly basis, monthly capacity factors were calculated for the three static model simulation methods. These results are shown in Figure 5 along with the monthly capacity factors calculated for the method employing the time-dependent performance simulation. As can be observed from Figure 5 , the distribution of the monthly capacity factors is similar among the four simulation methods and for any individual month the capacity factors for the static models remain nearly equal.

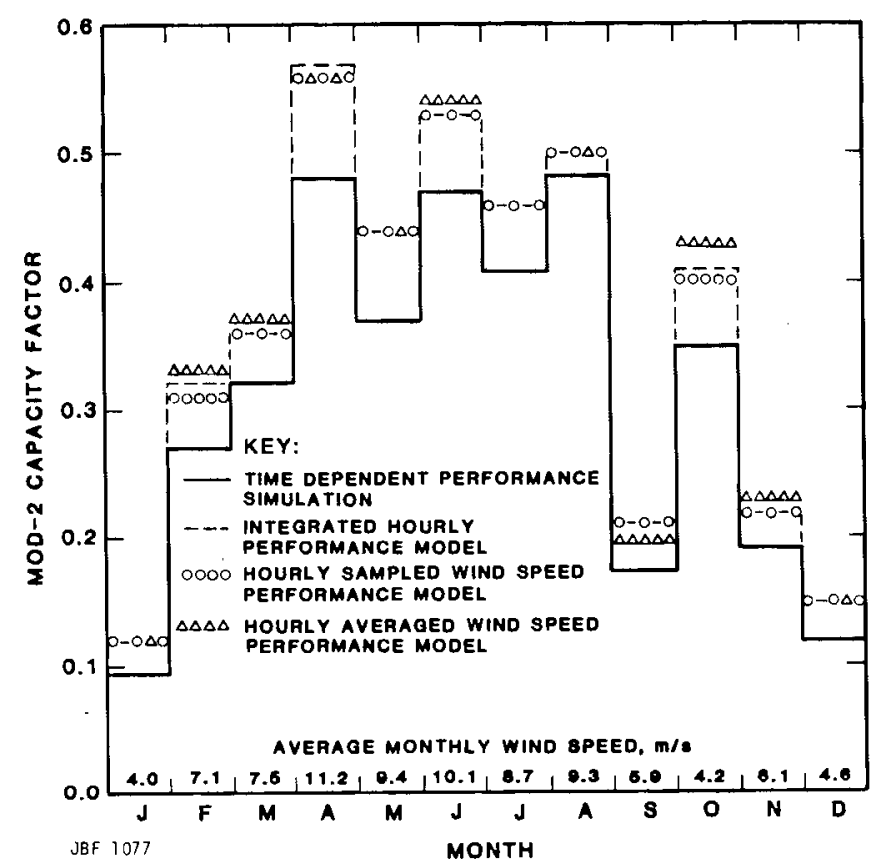

FIGURE 5. Monthly Capacity Factors for MOD-2 Output

\section{UTILITY DESCRIPTION}

The utility selected for analysis on this study was the Los Angeles Department of Water and Power (LADWP). LADWP is a municipal utility which serves the city of Los Angeles. The utility serves a load that is primarily located in urban and suburban areas. A large summer cooling load results in a strong summer peak. 
Based upon 1979 projections, the department's generation mix is predominantly oil-fired, and is projected to remain so through 1995. However, most new generation is planned as coal-fired, resulting in a $30 \%$ coal-fired capacity by 1995. LADWP has purchase and exchange agreements with the Bonneville Power Administration (BPA) whereby it receives power from BPA during peak load periods and replaces it during off-peak periods. BPA also acts as operating agent for the Hoover Dam power plant. The LADWP system equipment mix projected for 1995 also contained a significant amount of hydroelectric generation. In total, over $22 \%$ of LADWP's capacity was in the form of hydropower. Hydropower can respond quickly to load changes and is ideal for load-following applications. LADWP's pumped-storage hydro was not always used at rated capacity. Any unused pumped-hydro capacity was applied to satisfying utility operating reserve requirements. As a consequence, the sensitivity of LADWP's cost of generation to forecasting accuracy was mitigated by the availability of the pumped-hydro units. Table 3 is a summary of the LADWP equipment characteristics being used in this study, while Table 4 presents a summary of the LADWP financial parameters used. The values presented in Tables 3 and 4 were obtained from LADWP in 1979 during a study (Neal 1980) that JBF performed for the Electric Power Research Institute (EPRI). However, they may not reflect current (1981) LADWP projections.

\section{UTILITY ANALYSIS}

A utility cannot rely upon wind turbine output in the same manner as its conventional generating equipment. To study the effect of wind turbine generation as negative load on a utility system's unit commitment requires predicting system loads, $\mathrm{L}_{e}$, which are equal to the original predicted system loads, $L$, minus the output of the wind turbines, $W\left(L_{e}=L-W\right)$. Since the effective system loads $L_{e}$ are less than the original system loads, $L$, the addition of wind turbine generation reduces the capacity of conventional generation needed to satisfy the load requirements. However, the effective load $\mathrm{L}_{e}$ can be expected to fluctuate more than the system load, $L$, due to the stochastic nature of the wind power. As a result, in order to maintain the same system 
TABLE 3. Summary Data for LADWP (1995)

\begin{tabular}{|c|c|c|}
\hline & LADWP & \\
\hline Installed Capacity (MW) & 8716 & \\
\hline Projected System Peak Load (a) (MW) & 5730 & \\
\hline Reserve Margin (percent) & 23 & \\
\hline Generation Mix (percent) & Capacity & Energy \\
\hline Nuclear & 2 & 5 \\
\hline $0 i 1$ and Gas - Steam & 37 & 25 \\
\hline Coal - Steam & 32 & 52 \\
\hline Combustion Turbine & 1 & 0 \\
\hline Hydro & 13 & 10 \\
\hline Pumped Storage & 9 & 2 \\
\hline Purchase & 6 & 6 \\
\hline
\end{tabular}

Fuel costs (\$/MBtu - $1980 \$)$ MBu

Nuclear

$0 \mathrm{il}$ and Gas - Steam $\quad 5.4$

Coal - Steam 0.96

(a) Rate of Load Growth between 1979 and 1995 was assumed to be $2.3 \%$

TABLE 4. LADWP Financial Parameters

\begin{tabular}{lc}
\multicolumn{1}{c}{ Parameter } & Value \\
\cline { 1 - 1 } Weighted Cost of Capital (percent) & 6.5 \\
Discount Rate (percent) & 6.5 \\
Federal and State Income Tax (percent) & 0 \\
Property Tax (percent) & 0 \\
Investment Tax Credit & 0 \\
General Inflation Rate (percent) & 6.0 \\
Fuel Cost Inflation Rate (percent) & 7.5 \\
Insurance Fraction plus "In Lieu & 2.5 \\
of Taxes" Fraction &
\end{tabular}


reliability after wind turbines have been added to its equipment mix, a utility would have to increase its spinning reserve requirements. The amount of additional spinning reserve capacity needed is partially a function of how well wind speeds (wind turbine power) can be forecast. This need for additional generation results in an increase in utility production costs that has to be applied against a wind turbine's economic value.

One objective of this study was to identify the impact of wind speed sampling rate and wind turbine performance simulation techniques on utility operation and economics. The method used to perform the analyses is represented in Figure 6.

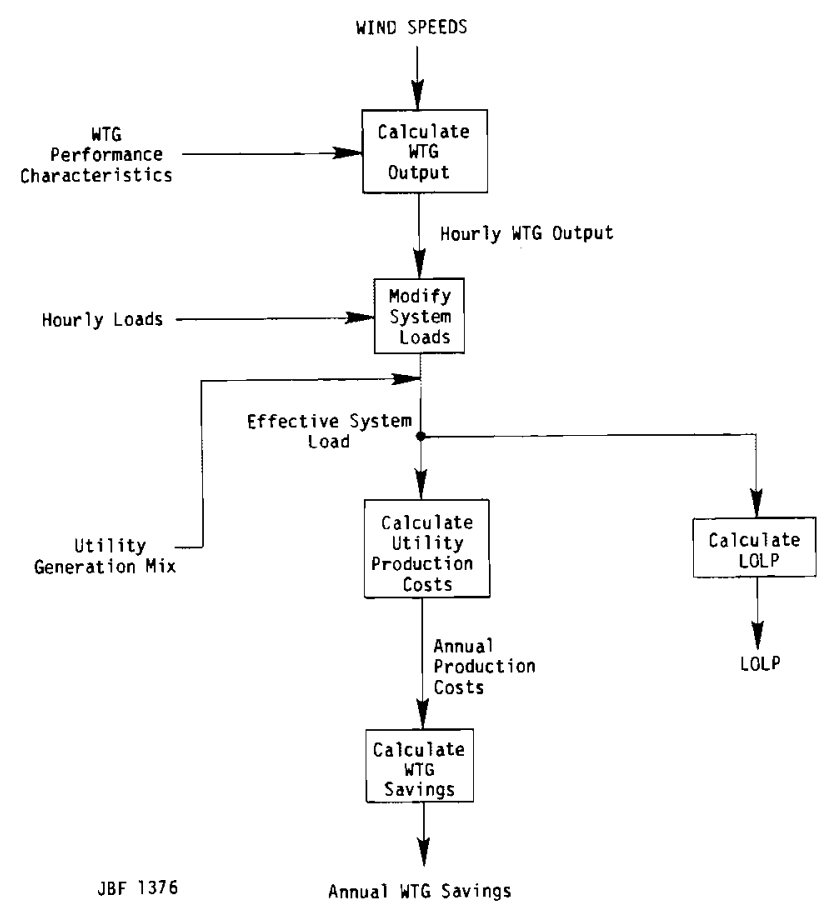

FIGURE 6. WTG Value Analysis Method

The initial step in this method is to establish a base case by calculating the annual cost of production for the utility without including WTG. This is accomplished by first projecting the utility generation mix and loads to the year of analysis (see Utility Description section). Using these projections 
as inputs to a production cost model, variable costs and reliability (loss of load probability - LOLP) are determined. (The LOLP is a reliability index which statistically expresses a utilitiy's ability to meet its loads and has the character of the probable number of times during a given period - i.e., a year - that the demand for power cannot be met because expected demand exceeds available capacity.)

The second step in the method is to calculate utility annual cost of production when WTG is included in the generating mix. Since utility production cost models usually require hourly input data, this step requires establishing an annual set of hourly WTG power outputs. These hourly power outputs are then used to modify the projected utility loads in order to determine the effective demand on conventional generation. Using the effective loads as input to a production cost model, a new set of variable costs and LOLP values are calculated. Comparing these figures to those calculated in the base case results in a determination of the impact of the WTG on utility variable costs and reliability. By performing this process using wind turbine performance simulation techniques, their effect on utility operations and economics can be estimated.

The addition of WTG units to a utility's generation mix has two major impacts. The first is that less online conventional electric generation is needed to satisfy system load requirements. The second is that the availability of WTG increases the reliability (lowers system LOLP) of the utility generating system. The first impact results in a reduction in utility production costs. The effect of the second impact is on utility planning and results in a reduction in the magnitude of conventional capacity that must be maintained by the utility.

To a large extent, the daily operation of a utility deals with dispatching generating equipment to meet load requirements at minimum cost. The equipment dispatched must have the ability to follow fluctuations in system demand. The equipment made available for dispatching is selected from the utility's generation mix and is typically based upon projections of next-day load requirements. The addition of WTG will decrease the utility's need for conventional capacity, 
but because of the stochastic nature of wind power, will increase the need for conventional units that can respond quickly to changes in system demand.

Thus, the daily mix (as well as capacity) of equipment selected for dispatching when WTG is part of the utility system will be different than it would have been without the availability of wind power. Utility planning, on the other hand, is done for some time frame, perhaps 10 to $25 \mathrm{yr}$ in the future, with the objective of defining the generation mix that will reliably satisfy projected load requirements at the minimum total cost. By comparing the desired future generation mix with its current mix, a utility can define which and how much new generating capability it has to acquire.

Since long-term utility planning is performed for a future time period, any reduction in required capacity caused by the addition of WTG can be interpreted as a reduced utility need to install or purchase additional conventional generating capacity. Care must be taken in selecting the proposed generating capacity to be displaced. If future planned units have low incremental fuel costs, their displacement may result in the utility continuing to depend on existing equipment with higher fuel costs. As a result, the capacity displacement of low incremental cost electric plants by WTG may increase a utility's production costs which, in turn, might outweigh any fixed cost (capacity credit) savings generated by the deferral of the conventional capacity. This, in fact, is what would happen on the LADWP system as determined by the previous JBF study (Neal 1980). In that study the 1995 technical and economic impact of a distributed solar electric device on utility operation was analyzed for various utility systems. One of the utilities analyzed was LADWP. The study showed that a reduction in LADWP's addition of coal-fired capacity would require additional operation of oil-fired capacity. The resulting increase in fuel coast would more than offset any capital savings generated and would result in increasing LADWP's total cost of generation. Thus, for this study, a capacity displacement was not calculated although in the Results section LADWP's LOLP is presented for the cases studied.

A second objective of this study was to identify the impact of wind forecasting accuracy on utility operations, for a utility that has WTG as part 
of $i$ ts generation mix. Figure 7 presents the method used to perform this task. In order to have identified the effect that WTG and wind speed forecasting would have on utility operation, it was first necessary to examine standard utility procedures used in satisfying system demand. Appendix $C$ presents a description of current utility operating procedures that was derived from conversations with various utility personnel, especially operations personnel from LADWP.

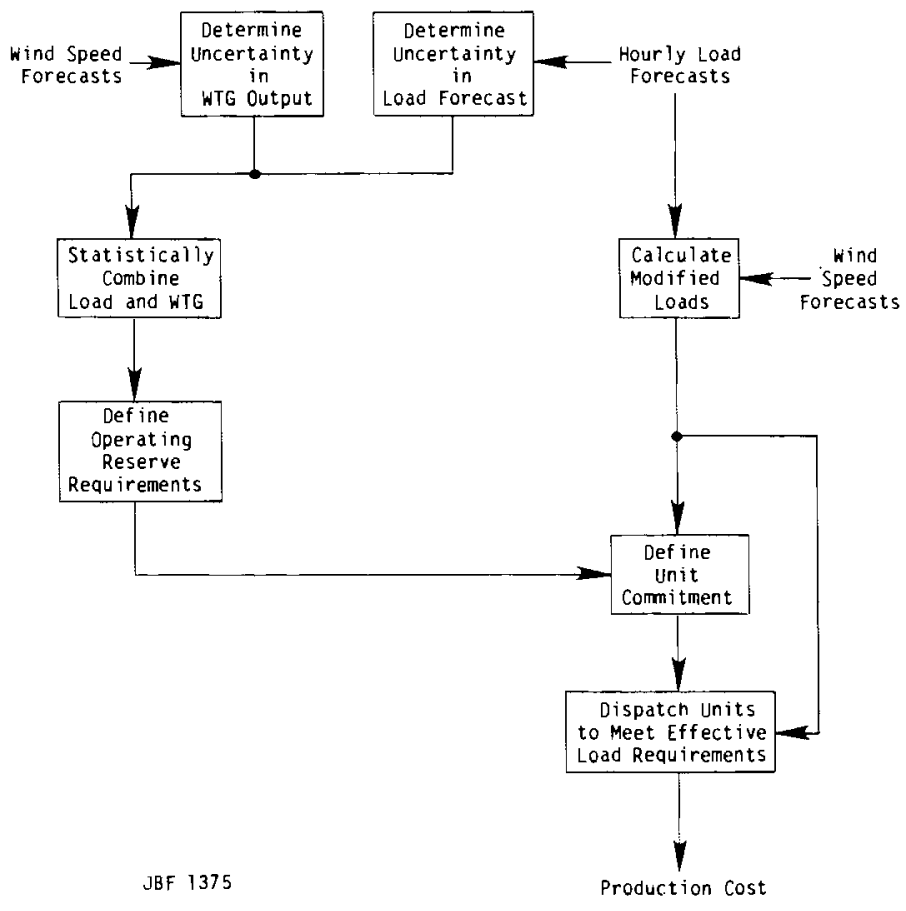

FIGURE 7. Wind Speed Forecasting Impact Analysis Method

The method presented in Figure 7 is consistent with current utility practices and is a reasonable representation of how a utility with wind turbine generation might operate. Current utility practice calls for daily forecasting of next-day loads that must be satisfied by conventional generation. A unit commitment of conventional sources is then performed which makes equipment available to satisfy the next day's demand economically and reliably. The approach taken to determine the impact of wind speed forecasting on utility 
operation was to modify unit commitment to reflect various levels in the accuracy with which the utility can forecast wind speed and then to calculate the resulting production costs by means of a utility dispatch model. The resulting production costs were compared to the case where wind speed can be predicted with $100 \%$ accuracy. By this means, the benefit of being able to accurately forecast wind speed (wind turbine power) was calculated.

Assuming the ability to predict wind speeds with $100 \%$ accuracy implies perfect knowledge of future wind speeds. Unit commitment, with WTG as part of the generation mix, is performed using an operating reserve equal to that normally carried by the utility. This case represents the base case for LADWP's cost of generation and was used to define the cost penalty that would occur from LADWP's inability to accurately forecast wind speed.

The method presented in Figure 7 uses estimates of wind speed forecasting accuracy to define the uncertainty in predicting WTG array power. The uncertainty in predicting WTG array power is then statistically combined (see Figure 8) with uncertainty in meeting future (next-day) loads with conventional equipment. The resulting "total system" uncertainty in meeting load requirements is subsequently used to calculate the level of operating reserves required to ensure a reliable operating system when WTG is a part of the generation $\operatorname{mix}$.

To perform a complete analysis of the power performance of a wind turbine generator array it would be necessary to define the power performance of the individual WTG units comprising the array. This would require knowledge of the wind resource at each site. Since suitable wind speed data from an array of anemometers was not available for this study, it was assumed the performance of a WTG array can be represented by generalizing the power performance of a representative WTG installation. (Because wind speed and direction vary spatially, the average performance of an array of wind installations will not, in general, be equal to the performance of any one unit operating alone.) Average array power output in the Pacific coast region can be assumed to be a linear function of an array's mean wind speed (Justus 1977): 


$$
P_{\text {array }}=\left(-0.42+1.14 \frac{\bar{V}}{V_{r}}\right) P_{r}
$$

where $P_{\text {array }}$ is array average output power in $M W$

$P_{r}$ is rated array power in MW

$V_{r}$ is WTG rated wind speed (m/s)

$\bar{V}$ is array mean wind speed $(\mathrm{m} / \mathrm{s})$.

If the above equation is used to forecast array power output, then the root mean square (RMS) deviation of wind speed forecasts about array mean wind speed is:

$$
\sigma \bar{V}_{f}=\sqrt{\frac{\sum_{1}^{n}\left(\bar{V}-\bar{V}_{f}\right)^{2}}{n-1}}
$$

where $\bar{V}_{f}$ is the forecast array mean wind speed

$\sigma \bar{V}_{f}$ is the RMS deviation of the forecast speed about the actual

array mean speed; this is also known as the root mean square error (RMSE)

$\mathrm{n}$ is the number of wind speed samples.

From the equations above, the expression for the RMSE of array power forecasts can be derived:

$$
\sigma_{p}=1.14 \frac{P_{r}}{V_{r}} \sigma \bar{V}_{f}
$$

where $\sigma_{p}$ is the RMSE of the array power forecast.

If it is assumed that the forecast of array mean wind speed $\left(\bar{V}_{f}\right)$ is normally distributed about the actual mean $(\bar{V})$, then forecast array power output is also normally distributed about actual array power output. This follows from the linear relationship between $P_{\text {array }}$ and $\bar{V}$ as well as between $\sigma_{p}$ and $\sigma \bar{V}_{f}$. It is realistic to assume that wind speed forecasting errors are normally distributed because most common wind forecasting techniques produce normally distributed errors, especially those based upon least-squares models. 
For this study the operating reserve levels normally maintained by LADWP were used and it was assumed that these reserves are sufficient to meet demand at least $99 \%$ of the time. Furthermore, differences in electrical demand and available generation are assumed to be normally distributed. These assumptions permitted viewing the operating reserves as being three times the RMS difference between load and available generation.

The method used in calculating the amount of operating reserves needed after the inclusion of WTG into the utility mix is shown in Figure 8 . This procedure assumes that the wind speed forecasting errors are also normally distributed and can be statistically combined with non-WTG operating reserve requirements in defining new system operating reserve requirements. The combined uncertainty in predicting utility capability in satisfying load requirements is used in defining the utility operating reserve requirements needed after the addition of WTG generation. By determining the operating reserves required for different levels of wind forecasting accuracy, $\sigma \bar{V}_{f}$, and then calculating the utility production costs associated with each, the relationship between wind forecasting accuracy and utility costs can be determined. From this relationship estimates can be made of the level of accuracy needed in wind speed forecasting to ensure that the maximum practical economic benefit is derived from WTG.

If wind speeds could not be predicted at a11, then utility unit commitment would be based upon load projections that ignore the availability of WTG power. This would result in a unit commitment that has sufficient spinning reserve to be able to withstand the loss of the largest conventional unit and al1 of the wind generation simultaneously. Operating a utility system in this manner would result in reduced savings generated by WTG units. 


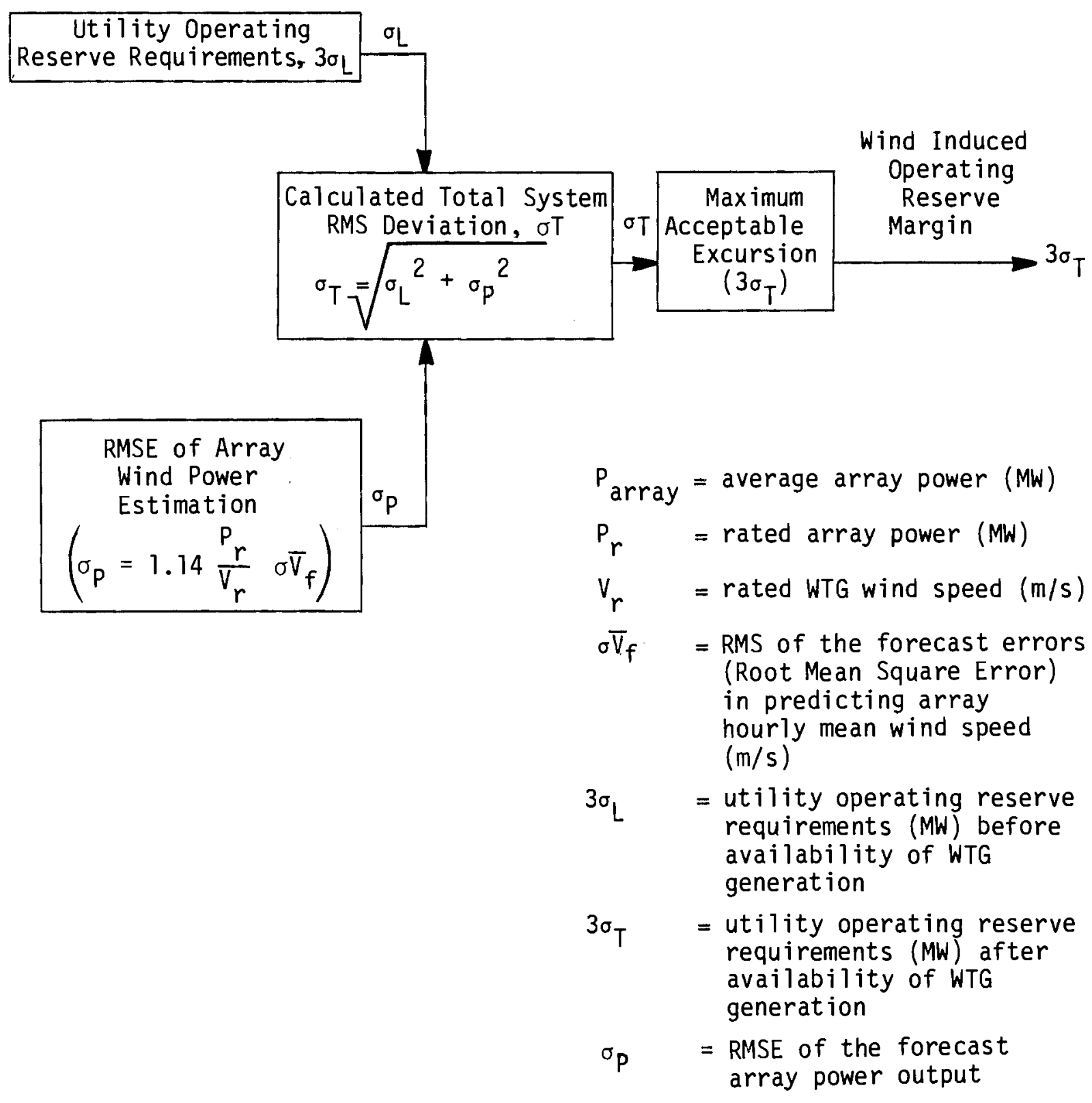

FIGURE 8. Method for Calculating Wind Induced Operating Reserve Margin 


\section{RESULTS}

This section presents the results generated from examining the sensitivity of the economic value of wind turbine generation to LADWP in 1995 as a function of wind speed sample frequency and wind turbine modeling technique. These results are presented for four different performance methods which simulate the performance of the MOD-2 operating in the San Gorgonio wind resource.

\section{EFFECT OF WIND TURBINE MODELING ON LADWP PRODUCTION COSTS}

The effects of integrating MOD-2 wind turbines into the projected 1995 LADWP system have been examined relative to the utility's production costs and reliability. The General Electric MPS production cost simulation model (GE 1977) was used in the analyses. Comparative results are presented in Tables 5 and 6 for the four methods used in predicting MOD-2 performance. For the analysis, it was assumed that MOD-2 wind turbines with rated capacity totaling $573 \mathrm{MW}$ ( $10 \%$ of projected 1995 LADWP peak load), were integrated into the LADWP system.

Table 5 presents the impact each of the four performance simulation methods has on the LADWP production costs and reliability. The production cost savings for the three methods utilizing the static model are nearly identical. However, the time-dependent performance simulation produces a much lower (approximately 13\%) value for the energy expected from the MOD-2. This is a result of the characteristic that the time-dependent performance simulation calculates more and longer downtimes and fewer periods during which the machine operates at rated power than the static models. It should be noted that using average hourly wind speeds resulted in the highest estimate for wind turbine energy produced, and of the three methods making use of the static model it had the least impact on system reliability. Both results are due to the hourly averaging, which reduces the variability of the wind speed.

Table 6 presents the average cost of fuel displaced by the four performance simulations methods as well as the distribution of the thermal fuel that was displaced by the wind turbine generation. For all four methods, wind 
TABLE 5. Effect of MOD-2 Performance on Production Costs and Reliability, Projected 1995 LADWP System

Total WTG Capacity $=573 \mathrm{MW}(10 \%$ of projected peak 1oad)

\begin{tabular}{|c|c|c|c|}
\hline $\begin{array}{l}\text { Method for Projecting } \\
\text { MOD-2 Performance }\end{array}$ & $\begin{array}{l}\text { MOD-2 } \\
\text { Capacity } \\
\text { Factor } \\
\end{array}$ & $\begin{array}{l}\text { Production Cost } \\
\text { Savings, } \$ 106(a)\end{array}$ & $\begin{array}{l}\text { LOLP } \\
\text { Events/ } \\
\text { Year } \\
\end{array}$ \\
\hline Baseline & -- & -- & 0.320 \\
\hline $\begin{array}{l}\text { Time-Dependent } \\
\text { Performance Simulation } \\
\text { (2-Min Wind Speeds) }\end{array}$ & 0.312 & 50.7 & 0.215 \\
\hline $\begin{array}{l}\text { Integrated Hourly } \\
\text { Performance Mode1 } \\
\text { (2-Min Wind Speeds) }\end{array}$ & 0.356 & 57.9 & 0.191 \\
\hline $\begin{array}{l}\text { Hourly Sampled Wind } \\
\text { Speed Performance Mode } 1 \\
\text { (Hourly 2-Min Wind } \\
\text { Speeds) }\end{array}$ & 0.355 & 56.1 & 0.201 \\
\hline $\begin{array}{l}\text { Hourly Averaged Wind } \\
\text { Speed Performance Model } \\
\text { (Average Hourly Wind } \\
\text { Speeds) }\end{array}$ & 0.364 & 57.8 & 0.208 \\
\hline
\end{tabular}

(a) 1995 costs, expressed in 1980 dollars

TABLE 6. Incremental Savings and Fuel Displacement Projected 1995 LADWP System

\begin{tabular}{|c|c|c|c|}
\hline $\begin{array}{l}\text { Method for Projecting } \\
\text { MOD-2 Performance }\end{array}$ & $\begin{array}{c}\text { Average } \\
\text { Incrementa } 1 \\
\text { Savings, } \\
\$ / \mathrm{kWh} \\
\end{array}$ & 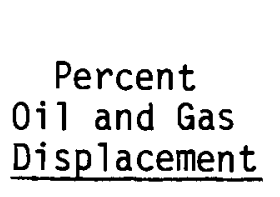 & $\begin{array}{l}\text { Percent Coa1 } \\
\text { Displacement }\end{array}$ \\
\hline $\begin{array}{l}\text { Time-Dependent } \\
\text { Performance Simulation }\end{array}$ & 3.25 & 56.8 & 43.2 \\
\hline $\begin{array}{l}\text { Integrated Hourly } \\
\text { Performance Model }\end{array}$ & 3.24 & 56.4 & 43.6 \\
\hline $\begin{array}{l}\text { Hourly Sampled Wind } \\
\text { Speed Performance Model }\end{array}$ & 3.17 & 54.4 & 45.5 \\
\hline $\begin{array}{l}\text { Hourly Averaged Wind } \\
\text { Speed Performance Model }\end{array}$ & 3.16 & 54.9 & 45.1 \\
\hline
\end{tabular}


power displaced slightly more oil and gas than it did coal. Another interesting result presented was that although the time-dependent performance simulation had the lowest capacity factor of the four methods (Table 5), it produced the highest average displaced fuel cost savings. This resulted directly from the fact that this method displaced a higher percentage of $0 i 1$ and gas than the other three methods. Unfortunately, due to the decrease in energy production the cost-to-benefit ratio works against the results using the time-dependent model.

A stream of utility payments over the life of an asset can be converted into an equivalent single-year payment through a factor known as an annual fixed-charge rate (FCR). This fixed-charge rate is a condensation of utility financial parameters and present value computations. A complete discussion of how the FCR is calculated can be found in Doane (1976). The fixed-charge rate calculated for LADWP, based upon the financial parameters shown in Table 4 , is 0.10. Using a FCR of 0.10 and assuming that fuel costs and inflation beyond the year 1995 will grow at the same rate, the equivalent single-year value of the 1 ife-cycle stream of savings calculated using the four performance simulation methods is shown in Table 7. Since, as discussed before, it is not economically appropriate to include a capacity displacement savings for LADWP in 1995, the marginal values presented in Table 7 represent an approximation of the total amount LADWP would be justified in spending on the installation of MOD-2 wind turbines. Again, note the $12 \%$ reduction in value calculated using the time-dependent simulation. (Table 7 also includes estimates of MOD-2 capacity costs.)

\section{SENSITIVITY OF LADWP PRODUCTION COSTS TO WIND FORECASTING}

The sensitivity of the economic impact of the MOD-2 wind turbines on the LADWP generating system to wind forecasting accuracy is presented in this section. The General Electric weekly production cost simulation model, WEEK PC, was used for this analysis.

To determine the limits of the impact wind forecasting could have on utility operations and costs, the operation of the LADWP system was simulated 
TABLE 7. Effect of MOD-2 Performance Simulation on MOD-2 Value Total WTG Capacity $=573$ MW (10\% of Projected Peak Load)

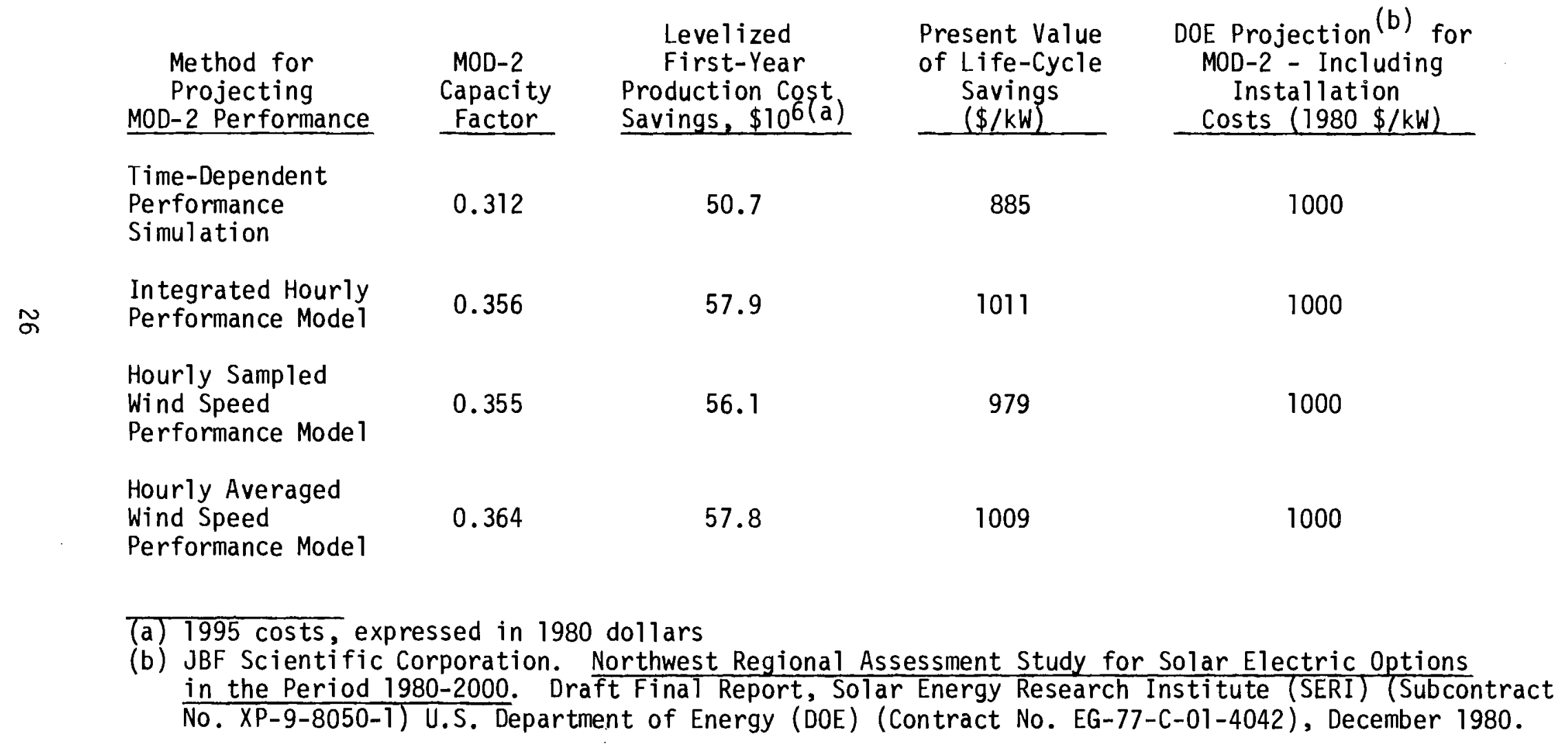


assuming both the ability to forecast wind speeds with a $100 \%$ confidence level and the complete inability to forecast wind speed ( $0 \%$ confidence level). To analyze these impacts, 2 weeks were selected: the first week in July and the first week in 0ctober. The week in July was selected for analysis because it contains LADWP's peak hourly load. The week in October was selected for analysis because it contained a load profile more representative of periods of low demand. (Typical diurnal and weekly load profiles for October and July are shown in Appendix D.) By performing the analysis for these 2 weeks, the sensitivity of the results to load profile could be examined.

Tables 8 and 9 present the equipment dispatched for the 0 to $100 \%$ wind forecasting confidence cases as well as a base case where wind is excluded from the LADWP generation mix for the 2 weeks studied. The inability to forecast wind speeds accurately results in a cost penalty that reduces the savings generated by the wind turbines. A portion of this penalty came from the need to dispatch more conventional generation to cover the increase in operating reserve requirements that result from the greater uncertainty in predicting WTG output. For example, Table 8 shows that in July, 1924 more MWh of conventional generation are required when there is zero confidence level in being able to predict array mean wind speed than when the array mean wind speed can be predicted with $100 \%$ confidence. The remainder of the July cost penalty comes from the shift in fuel type used. The "zero confidence case" requires a higher percentage of oil-fired generation represents the most expensive generation available, this shift to $0 i 1$ also results in a cost penalty that must be incurred due to the utility's inability to accurately predict array mean wind speeds. Similar results can be seen for October in Table 9.

Figure 9 presents production costs savings lost as a function of the standard deviation of the error, root mean square error (RMSE), in predicting array mean wind speed for the first week in October and July.

It should be noted that for this study the RMSE of the wind speed forecasts was assumed independent of forecast projection time. The projection time of a forecast is usually given as the number of hours from the time 
TABLE 8. Impact of 0 and 100\% Accuracy in Wind Speed Forecasting on LADWP 1995 Production Costs for the First Week in July

FUEL SUMMARY BY FUEL TYPE - JULY 1979 SAN GORGONIO WIND SPEEDS

\begin{tabular}{|c|c|c|c|c|c|c|c|}
\hline Case & Fue 1 & $\begin{array}{c}\text { Capacity } \\
\text { (MW) }\end{array}$ & $\begin{array}{l}\text { Energy } \\
\text { Output } \\
\text { (MWH) }\end{array}$ & $\begin{array}{c}\text { Fue }+ \\
\text { Startup } \\
(\$)\end{array}$ & $\begin{array}{c}\text { Fuel } \\
\text { Consumption }\end{array}$ & $\begin{array}{l}\text { Fuel + } \\
\text { Start } \\
\$ / \mathrm{MWH} \\
\end{array}$ & $\begin{array}{l}\text { Cap. } \\
\text { Fac. }\end{array}$ \\
\hline 0 Wind & $\begin{array}{l}\text { LS OIL } \\
\text { DIST OIL } \\
\text { CORO COAL } \\
\text { IPP COAL } \\
\text { MOH COAL } \\
\text { NAV COAL } \\
\text { BASE COAL } \\
\text { NUCLEAR } \\
\text { GAS N\&D } \\
\text { TOTAL }\end{array}$ & $\begin{array}{r}250.0 \\
1511.0 \\
0.0 \\
810.0 \\
111.0 \\
402.0 \\
352.0 \\
120.0 \\
1237.0 \\
4793.0\end{array}$ & $\begin{array}{r}0.0 \\
132677.0 \\
0.0 \\
136080.0 \\
18648.0 \\
67536.0 \\
59136.0 \\
20160.0 \\
76010.0 \\
510248.0\end{array}$ & $\begin{array}{r}0.0 \\
17343761.0 \\
0.0 \\
3755136.0 \\
561280.0 \\
1499450.0 \\
1263091.0 \\
252540.0 \\
991186.0 \\
34586545.0\end{array}$ & $\begin{aligned} 0.0 & \text { BBL } \\
221370.0 & \text { BBL } \\
0.0 & \text { TONS } \\
67200.0 & \text { TONS } \\
11044.0 & \text { TONS } \\
32302.0 & \text { TONS } \\
22604.0 & \text { TONS } \\
216.0 & \text { BBTU } \\
728905.0 & \text { MCF }\end{aligned}$ & $\begin{array}{r}0.0 \\
130.7 \\
0.0 \\
27.6 \\
30.1 \\
22.2 \\
21.4 \\
12.5 \\
130.4\end{array}$ & $\begin{array}{l}0.0 \\
0.52 \\
0.0 \\
1.00 \\
1.00 \\
1.00 \\
1.00 \\
1.00 \\
0.37\end{array}$ \\
\hline $\begin{array}{l}10 \% \text { Wind }(a) \\
\text { Zero Forecast } \\
\text { Confidence }\end{array}$ & $\begin{array}{l}\text { LS OIL } \\
\text { DIST OIL } \\
\text { CORO COAL } \\
\text { IPP COAL } \\
\text { MOH COAL } \\
\text { NAV COAL } \\
\text { BASE COAL } \\
\text { NUCLEAR } \\
\text { GAS N\&D } \\
\text { TOTAL }\end{array}$ & $\begin{array}{r}250.0 \\
1511.0 \\
0.0 \\
810.0 \\
111.0 \\
402.0 \\
352.0 \\
120.0 \\
1237.0 \\
4793.0\end{array}$ & $\begin{array}{r}0.0 \\
94766.0 \\
0.0 \\
135936.0 \\
18428.0 \\
67536.0 \\
58960.0 \\
20160.0 \\
43026.0 \\
440736.0\end{array}$ & $\begin{array}{r}0.0 \\
13122837.0 \\
0.0 \\
3751470.0 \\
555549.0 \\
1499450.0 \\
1258621.0 \\
252540.0 \\
5749600.0 \\
26752180.0\end{array}$ & $\begin{aligned} 0.0 & \text { BBL } \\
167495.0 & \text { BBL } \\
0.0 & \text { TONS } \\
67134.0 & \text { TONS } \\
10932.0 & \text { TONS } \\
32302.0 & \text { TONS } \\
22524.0 & \text { TONS } \\
216.0 & \text { BBTU } \\
422842.0 & \text { MCF }\end{aligned}$ & $\begin{array}{r}0.0 \\
138.5 \\
0.0 \\
27.6 \\
30.1 \\
22.2 \\
21.3 \\
12.5 \\
133.6\end{array}$ & $\begin{array}{l}0.0 \\
0.37 \\
0.0 \\
1.00 \\
0.99 \\
1.00 \\
1.00 \\
1.00 \\
0.21\end{array}$ \\
\hline $\begin{array}{l}10 \% \text { Wind }(a) \\
100 \% \\
\text { Forecast } \\
\text { Confidence }\end{array}$ & $\begin{array}{l}\text { LS OIL } \\
\text { DIST OIL } \\
\text { CORO COAL } \\
\text { IPP COAL } \\
\text { MOH COAL } \\
\text { NAV COAL } \\
\text { BASE COAL } \\
\text { NUCLEAR } \\
\text { GAS N\&D } \\
\text { TOTAL }\end{array}$ & $\begin{array}{r}250.0 \\
1511.0 \\
0.0 \\
810.0 \\
111.0 \\
402.0 \\
352.0 \\
120.0 \\
1237.0 \\
4793.0\end{array}$ & $\begin{array}{r}0.0 \\
88313.0 \\
0.0 \\
136080.0 \\
18503.0 \\
67536.0 \\
59136.0 \\
20160.0 \\
51009.0 \\
438812.0\end{array}$ & $\begin{array}{r}0.0 \\
12426191.0 \\
0.0 \\
3755136.0 \\
557492.0 \\
1499450.0 \\
1263091.0 \\
252540.0 \\
7006230.0 \\
26191169.0\end{array}$ & $\begin{aligned} 0.0 & \text { BBL } \\
158604.0 & \text { BBL } \\
0.0 & \text { TONS } \\
67200.0 & \text { TONS } \\
10970.0 & \text { TONS } \\
32302.0 & \text { TONS } \\
22604.0 & \text { TONS } \\
216.0 & \text { BBTU } \\
514674.0 & \text { MCF }\end{aligned}$ & $\begin{array}{r}0.0 \\
140.7 \\
0.0 \\
27.6 \\
30.1 \\
22.2 \\
21.4 \\
12.5 \\
137.4\end{array}$ & $\begin{array}{l}0.0 \\
0.35 \\
0.0 \\
1.00 \\
0.99 \\
1.00 \\
1.00 \\
1.00 \\
0.25\end{array}$ \\
\hline
\end{tabular}

(a) 573 MW of online WTG capacity 
TABLE 9. Impact of 0 and $100 \%$ Accuracy in Wind Speed Forecasting on LADWP 1995 Production Costs for the First Week in October

FUEL SUMMARY BY FUEL TYPE - OCTOBER 1979 SAN GORGONIO WIND SPEEDS

\begin{tabular}{|c|c|c|c|c|c|c|c|c|}
\hline & Case & Fue 1 & $\begin{array}{l}\text { Capacity } \\
\text { (MW) }\end{array}$ & $\begin{array}{l}\text { Energy } \\
\text { Output } \\
\text { (MWH) } \\
\end{array}$ & $\begin{array}{c}\text { Fuel }+ \\
\text { Startup } \\
(\$)\end{array}$ & $\begin{array}{c}\text { Fuel } \\
\text { Consumption } \\
\end{array}$ & $\begin{array}{l}\text { Fuel }+ \\
\text { Start } \\
\$ / \text { MWH } \\
\end{array}$ & $\begin{array}{l}\text { Cap. } \\
\text { Fac. }\end{array}$ \\
\hline & 0 Wind & $\begin{array}{l}\text { LS OIL } \\
\text { DIST OIL } \\
\text { CORO COAL } \\
\text { IPP COAL } \\
\text { MOH COAL } \\
\text { NAV COAL } \\
\text { BASE COAL } \\
\text { NUCLEAR } \\
\text { GAS N\&D } \\
\text { TOTAL }\end{array}$ & $\begin{array}{r}250.0 \\
1511.0 \\
0.0 \\
810.0 \\
111.0 \\
402.0 \\
352.0 \\
120.0 \\
1237.0 \\
4793.0\end{array}$ & $\begin{array}{r}0.0 \\
160306.0 \\
0.0 \\
136080.0 \\
18648.0 \\
67536.0 \\
59136.0 \\
20160.0 \\
91070.0 \\
552936.0\end{array}$ & $\begin{array}{r}0.0 \\
20482696.0 \\
0.0 \\
3755136.0 \\
561280.0 \\
1499450.0 \\
1263091.0 \\
252540.0 \\
11931101.0 \\
39745295.0\end{array}$ & $\begin{aligned} 0.0 & \text { BBL } \\
261434.0 & \text { BBL } \\
0.0 & \text { TONS } \\
67200.0 & \text { TONS } \\
11044.0 & \text { TONS } \\
32302.0 & \text { TONS } \\
22604.0 & \text { TONS } \\
216.0 & \text { BBTU } \\
877448.0 & \text { MCF }\end{aligned}$ & $\begin{array}{r}0.0 \\
127.8 \\
0.0 \\
27.6 \\
30.1 \\
22.2 \\
21.4 \\
12.5 \\
131.0\end{array}$ & $\begin{array}{l}0.0 \\
0.63 \\
0.0 \\
1.00 \\
1.00 \\
1.00 \\
1.00 \\
1.00 \\
0.44\end{array}$ \\
\hline బี & $\begin{array}{l}10 \% \text { Wind }(a) \\
\text { Zero Forecast } \\
\text { Confidence }\end{array}$ & $\begin{array}{l}\text { LS OIL } \\
\text { DIST OIL } \\
\text { CORO COAL } \\
\text { IPP COAL } \\
\text { MOH COAL } \\
\text { NAV COAL } \\
\text { BASE COAL } \\
\text { NUCLEAR } \\
\text { GAS N\&D } \\
\text { TOTAL }\end{array}$ & $\begin{array}{r}250.0 \\
1511.0 \\
0.0 \\
810.0 \\
111.0 \\
402.0 \\
352.0 \\
120.0 \\
1237.0 \\
4793.0\end{array}$ & $\begin{array}{r}0.0 \\
143770.0 \\
0.0 \\
136080.0 \\
18648.0 \\
67536.0 \\
59136.0 \\
20160.0 \\
86125.0 \\
531455.0\end{array}$ & $\begin{array}{r}0.0 \\
18574229.0 \\
0.0 \\
3755136.0 \\
561280.0 \\
1499450.0 \\
1263091.0 \\
252540.0 \\
11356403.0 \\
37262136.0\end{array}$ & $\begin{aligned} & 0.0 \text { BBL } \\
& 237075.0 \text { BBL } \\
& 0.0 \text { TONS } \\
& 67200.0 \text { TONS } \\
& 11044.0 \text { TONS } \\
& 32302.0 \text { TONS } \\
& 22604.0 \text { TONS } \\
& 216.0 \text { BBTU } \\
& 835184.0 \mathrm{MCF}\end{aligned}$ & $\begin{array}{r}0.0 \\
129.2 \\
0.0 \\
27.6 \\
30.1 \\
22.2 \\
21.4 \\
12.5 \\
131.0\end{array}$ & $\begin{array}{l}0.0 \\
0.57 \\
0.0 \\
1.00 \\
1.00 \\
1.00 \\
1.00 \\
1.00 \\
0.41\end{array}$ \\
\hline & $\begin{array}{l}10 \% \text { Wind }(a) \\
100 \% \\
\text { Forecast } \\
\text { Confidence }\end{array}$ & $\begin{array}{l}\text { LS OIL } \\
\text { DIST OIL } \\
\text { CORO COAL } \\
\text { IPP COAL } \\
\text { MOH COAL } \\
\text { NAV COAL } \\
\text { BASE COAL } \\
\text { NUCLEAR } \\
\text { GAS N\&D } \\
\text { TOTAL }\end{array}$ & $\begin{array}{r}250.0 \\
1511.0 \\
0.0 \\
810.0 \\
111.0 \\
402.0 \\
352.0 \\
120.0 \\
1237.0 \\
4793.0\end{array}$ & $\begin{array}{r}0.0 \\
148907.0 \\
0.0 \\
136080.0 \\
18648.0 \\
67536.0 \\
59136.0 \\
20160.0 \\
80138.0 \\
530604.0\end{array}$ & $\begin{array}{r}0.0 \\
19168254.0 \\
0.0 \\
3755136.0 \\
561280.0 \\
1499450.0 \\
1263091.0 \\
252540.0 \\
10393157.0 \\
36892909.0\end{array}$ & $\begin{array}{rl}0.0 & \mathrm{BBL} \\
244657.0 & \mathrm{BBL} \\
0.0 & \text { TONS } \\
67200.0 & \text { TONS } \\
11044.0 & \text { TONS } \\
32302.0 & \text { TONS } \\
22604.0 & \text { TONS } \\
216.0 & \text { BBTU } \\
764343.0 \mathrm{MCF}\end{array}$ & $\begin{array}{r}0.0 \\
128.7 \\
0.0 \\
27.6 \\
30.1 \\
22.2 \\
21.4 \\
12.5 \\
129.7\end{array}$ & $\begin{array}{l}0.0 \\
0.59 \\
0.0 \\
1.00 \\
1.00 \\
1.00 \\
1.00 \\
1.00 \\
0.39\end{array}$ \\
\hline
\end{tabular}

(a) 573 MW of online WTG capacity 


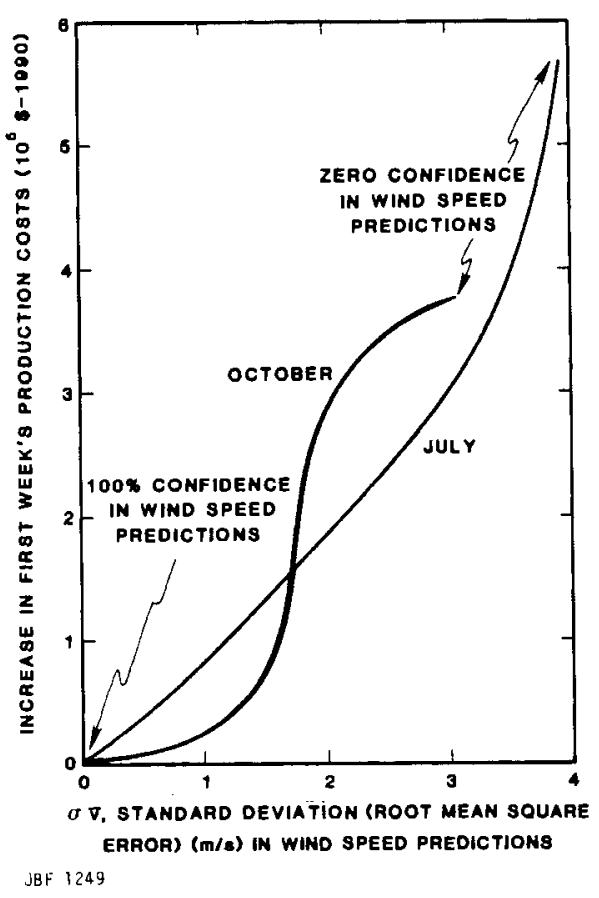

FIGURE 9. Production Cost Sensitivity to RMS Error in Wind Speed Prediction

the prediction is made until its expected occurrence. If wind speed forecasts remain accurate far enough into the future, they may provide sufficient visibility for unit committment as well as dispatching. On the other hand, if they are only accurate for a short time period, they may be rendered useful only for dispatching decisions. Furthermore, the forecasts may have to be updated frequently, depending upon the rate of decay of their accuracy with time.

Certainly the manner in which wind forecasts are produced and used will affect their economic value. Though not addressed specifically in this report, the variation of forecast accuracy with projection time could be an important factor to consider at many potential wind turbine sites.

The results presented in Figure 9 for October indicate that there is a range of RMSE's where production costs are very sensitive to the RMSE of the wind speed forecast. This range is between 1 and $2 \mathrm{~m} / \mathrm{s}$. Under the 
low load conditions of October, little or no savings is gained if winds cannot be predicted with an RMSE of less than $2.5 \mathrm{~m} / \mathrm{s}$.

The results for July, a period of high demand, show that production costs are continuously sensitive to the error of the forecast wind speed in the RMSE range of 0 to $4 \mathrm{~m} / \mathrm{s}$.

According to the second and third authors of this report, a preliminary study of objective wind speed forecasts developed for nine DOE candidate WTG sites revealed that RMSE's averaged $2.8 \mathrm{~m} / \mathrm{s}$ in the $\mathrm{fa} 11$ and $2.9 \mathrm{~m} / \mathrm{s}$ in the summer (the RMSE's were as $10 \mathrm{w}$ as $2.3 \mathrm{~m} / \mathrm{s}$ at some sites). If October is typical of periods of low demand and July of high electrical demand, then Figure 9 indicates that savings from the wind forecasts mentioned above would occur primarily during the months of high demand.

This example clearly illustrates that both load variation and wind forecasting accuracy by season should be considered in order to assess the value of wind forecasts to utilities using WTG.

Table 10 presents an example of the weekly savings that could be achieved if LADWP could accurately predict wind speeds. It presents the weekly production costs in July and 0ctober for the base case with zero wind on line. It also presents production costs for a $10 \%$ penetration of wind with 0 and $100 \%$ confidence in wind speed forecasting. By comparing the savings between the two wind speed forecast cases assuming a $10 \%$ wind penetration, the maximum weekly savings that could be generated by forecasting wind speeds was determined. These results are shown in Table 10 for the first weeks in July and October.

Assuming again that the 0ctober case is roughly representative of 6 months of lower demand and that July approximates 6 months of higher demand, the weekly savings from accurate forecasting can be estimated by averaging the savings for the 2 weeks shown in Table 10. The savings, under these assumptions, would total nearly 10 million dollars annually. This represents almost $20 \%$ of the 50 to 60 million dollars in production cost savings derived 
TABLE 10. Examples of Maximum Potential Benefit

From Accurate Wind Speed Forecasting

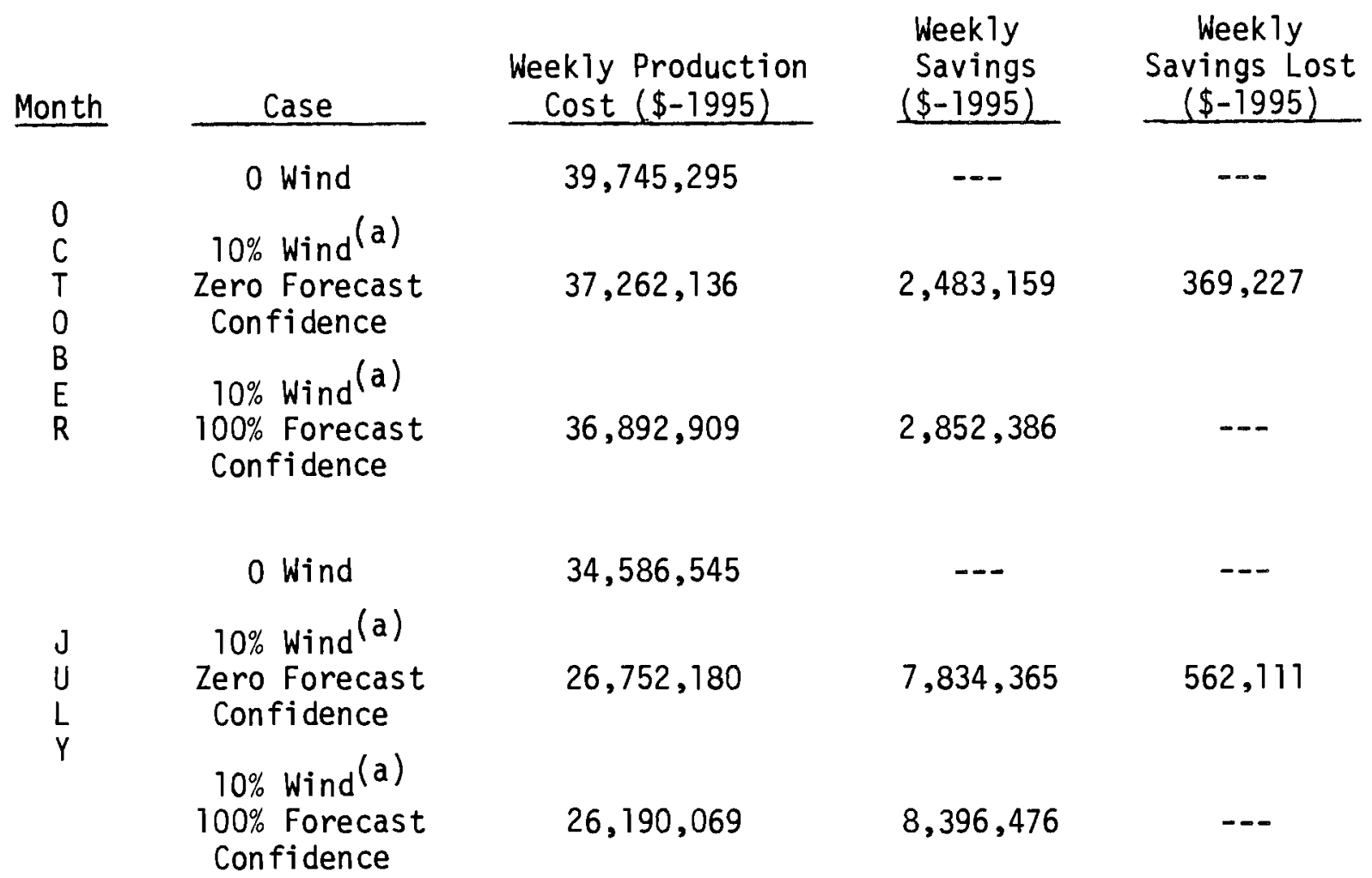

(a) $573 \mathrm{MW}$ of installed WTG Capacity

from WTG (see Table 7). Savings from forecasting could even be greater for utilities having more thermal generation than LADWP and no pumped hydro.

Assuming a wind speed forecast RMSE of $2.5 \mathrm{~m} / \mathrm{s}$, and then calculating annual savings from Figure 9 , also results in nearly 10 million dollars saved annualiy. Since wind speed forecasting RMSE's of $2.5 \mathrm{~m} / \mathrm{s}$ have already been achieved at some DOE candidate wind turbine sites, it is realistic to assume that state-of-the-art wind forecasts may provide substantial savings to LADWP and to other utilities that install a significant amount of WTG.

It must be emphasized that the economic value attributed to wind forecasting in this study is not generic. Factors such as the specific utility 
generation mix and inter-utility transactions may greatly affect wind-forecasting value. For example, savings from forecasting might be substantially greater than that demonstrated in this study if the utility has more thermal generation than LADWP and lacks hydro power. On the other hand, the purchase agreements of some utilities may render wind-forecasting value nil. For example, if a utility agrees to purchase a large amount of hydro-electric power for certain time periods, the hydro may provide sufficient reserves to cover the WTG much, or all, of the time. In this case, a decrease in the required spinning reserves (due to accurate wind forecasts) may have no effect on the cost of power production since the hydro must be paid for whether or not it is backing up the WTG. 
.

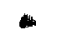

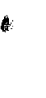




\section{RECOMMENDATIONS}

Because LADWP's generating system contains a significant fraction of hydroelectric generation (Table 3 ), it is not typical of many utilities. Consequently, it is not possible to generalize all results of this study. It is suggested, therefore, that additional studies be made in order to identify, in a more generic sense, the sensitivity of utility costs to wind turbine modeling techniques, wind speed sampling frequency, and wind speed forecasting accuracy. 


\section{REFERENCES}

Doane, J. 1976. The Cost of Energy From Utility-Owned Solar Electric Systems. Technical Report ERDA/JPL-1012-76/3, prepared by Jet Propulsion Laboratory for the U.S. Energy Research and Development Administration, Division of Solar Energy.

General Electric Company. 1977. "Monthly Production Simulation Program, Program Description Manual (MPS)." Systems Planning Section, Systems Engineering, Schenectady, New York.

Justus, C. G. 1978. Wind Energy Statistics for Large Arrays of Wind Turbines (Great Lakes and Pacific Coast Regions). Technical Report RLO/2439-77/2, prepared by Georgia Institute of Technology - School of Aerospace Engineering, for the Energy Research and Development Administration.

Miller, A. H. 1980. "Implications of the Effect of Wind Characteristics on the Operation of Large Wind Turbines." In Proceedings of the 15th Intersociety Energy Conversion Engineering Conference, Vol. 2, pp. 1154-1158, Seattle, Washington, August 18-22, 1980.

Neal, Robert. 1980. Assessment of Distributed Photovoltaic Electric Power Systems. Technical Report EPRI RP-11921, prepared by JBF Scientific Corporation for the Electric Power Research Institute, Palo Alto, California. 
APPENDIX A

REHABILITATION OF SAN GORGONIO WIND SPEEDS 


\section{APPENDIX A}

\section{REHABILITATION OF SAN GORGONIO WIND SPEEDS}

JBF Scientific Corporation found it necessary to rehabilitate wind speed data in various studies involved in evaluating the economic impact of wind turbine generation on utility operation. Consequently, the methods and models used to rehabilitate the 1979 San Gorgonio wind speed data were already available at the start of this study. The methods and models used are presented in this appendix.

The general expression for extrapolation wind speeds between two heights is:

$$
\left(\frac{V_{2}}{V_{1}}\right)=\left(\frac{H_{2}}{H_{1}}\right)^{\alpha}
$$

where $v_{1}, v_{2}=$ Wind speed, mph, at lower and upper heights

$\mathrm{H}_{1}, \mathrm{H}_{2}=$ Lower and upper heights, feet, above surface elevation

$\alpha=$ exponent for wind speed extrapolation.

For this study, site-specific alpha values that are a function of wind speed only were developed, as opposed to using general expressions such as the one-seventh power law (e.g., $\alpha=1 / 7$ for all points).

Figure A-1 illustrates the logical features of the rehabilitation process for constructing a "wind year" at hub height. The process uses existing data to the maximum extent possible. Annual average alpha values are used in the extrapolation process and the average wind speed for each hour and each month was used when observations at both heights are missing. The criteria for anomalous data was that the upper wind speed is less than $20 \%$ of the lower wind speed.

As shown in Figure $A-1$, there are five logical pathways for calculating wind speeds (at an elevation of $200 \mathrm{ft}$ ) from the existing observed values and statistical results: 


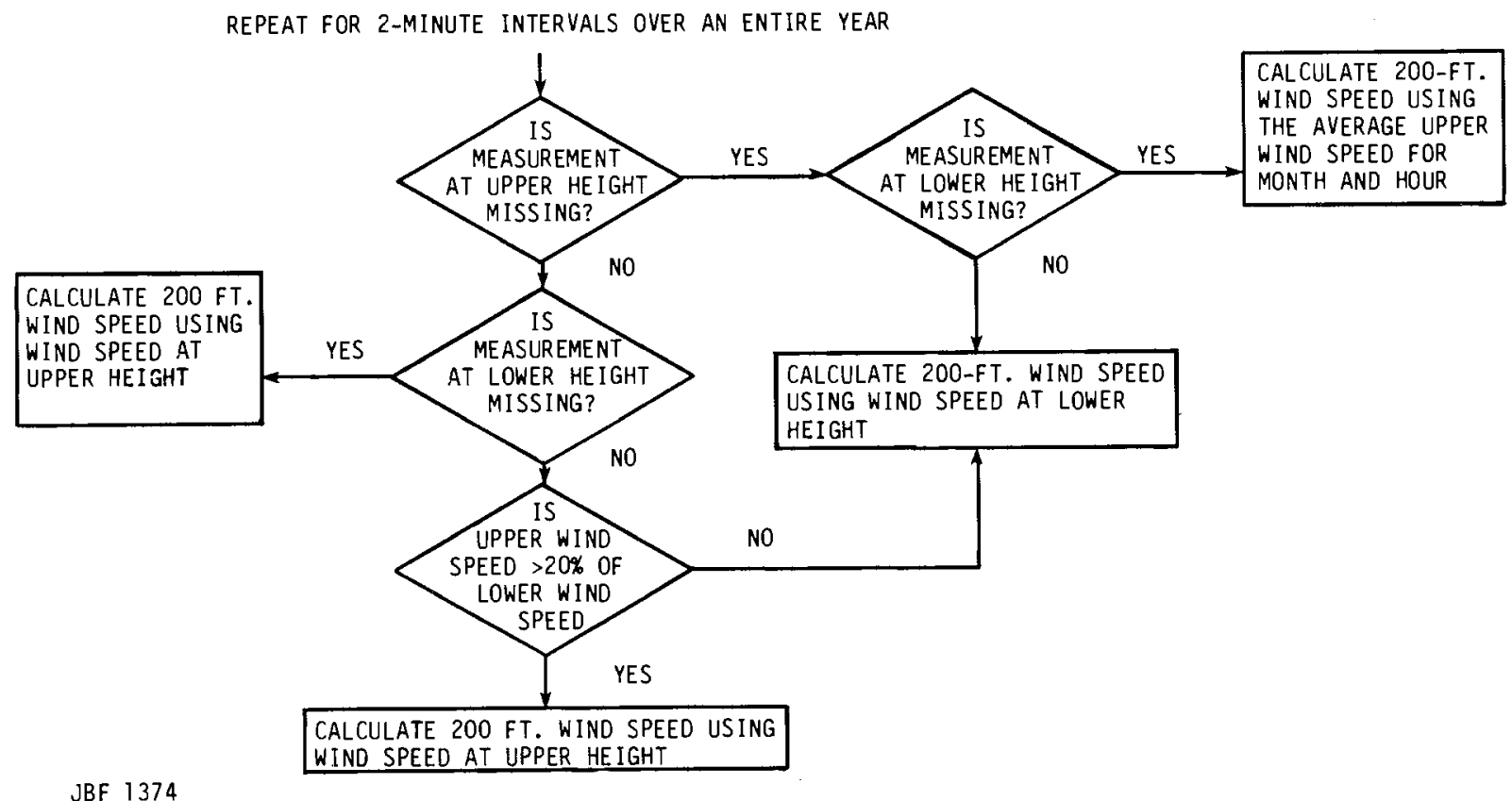

\section{FIGURE A-1. Wind Speed Rehabilitation Methodology}

1. When the wind speeds at both lower and upper measuring heights were available and the data are not anomalous, the upper elevation wind speed (at $150 \mathrm{ft}$ ) was extrapolated to $200 \mathrm{ft}$.

2. When wind speeds are available at both elevations and the data is anomalous, the lower elevation wind speed (at $30 \mathrm{ft}$ ) was extrapolated to $200 \mathrm{ft}$.

3. When only the lower elevation wind speed (at $30 \mathrm{ft}$ ) was available, it was extrapolated to $200 \mathrm{ft}$.

4. When only the upper elevation wind speed was available, it was extrapolated to $200 \mathrm{ft}$.

5. When observations at both elevations were missing, the average wind speed at the upper height for the corresponding hour and month was extrapolated to $200 \mathrm{ft}$.

This process was repeated for al1 possible 2-min observations over the year. The typical logical pathway was Number 1 , since most of the data points were neither missing nor anomalous. 
Extrapolation factors (alphas) for adjusting wind speeds between two heights were determined for $2 \mathrm{mph}$ wind speed intervals. The alphas used were the annual average of the individual alpha values in each wind speed interval.

Anomalous data are observations that are not consistent between the lower and upper heights and, therefore, were excluded from the calculations of extrapolation factors and statistical averages. In addition, anomalous data were replaced in the rehabilitation process.

For statistical averages, only points where the upper wind speed was less than $20 \%$ of the lower wind speed (i.e., $\alpha<-1$ ) were excluded from calculations due to anomalies. For this data, 5484 observations (or 2.1\% of total possible) were excluded. This anomalous data occurred almost exclusively ( $99 \%$ of the time) when the lower wind speed was less than $4.4 \mathrm{~m} / \mathrm{s}$, consequently, replacing these data had very little effect on the results of the study because the wind speeds introduced were near or below cut-in. These anomalies occurred throughout the year, but were concentrated in months with lower average wind speeds.

For calculation of extrapolation factors, two criteria were imposed for eliminating observations from calculating average alpha values in addition to the $\alpha<-1$ criterion. First, observations where either the lower or upper wind speed equals zero were eliminated to avoid errors in logarithmic calculations. For the 1979 San Gorgonio data, there were 1512 such observations. Finally, observations with $\alpha>2$ were excluded, since the upper wind speed in this case was considerably greater (by a factor of at least 9) than the lower elevation wind speed. There were 144 such observations. Therefore, in total, 7140 anomalous data points (or $3.1 \%$ of the available data points) were excluded from the alpha calculations.

Alpha values calculated for the San Gorgonio Pass are illustrated in Figure $A-2$. The alpha results are lower than expected for wind speeds between 2 and $10 \mathrm{mph}$, which was where a majority of the problems with anomalous data were identified. This result could be caused by a combined effect of the local topography and unidirectional winds. Above $12 \mathrm{mph}$ the alpha value 


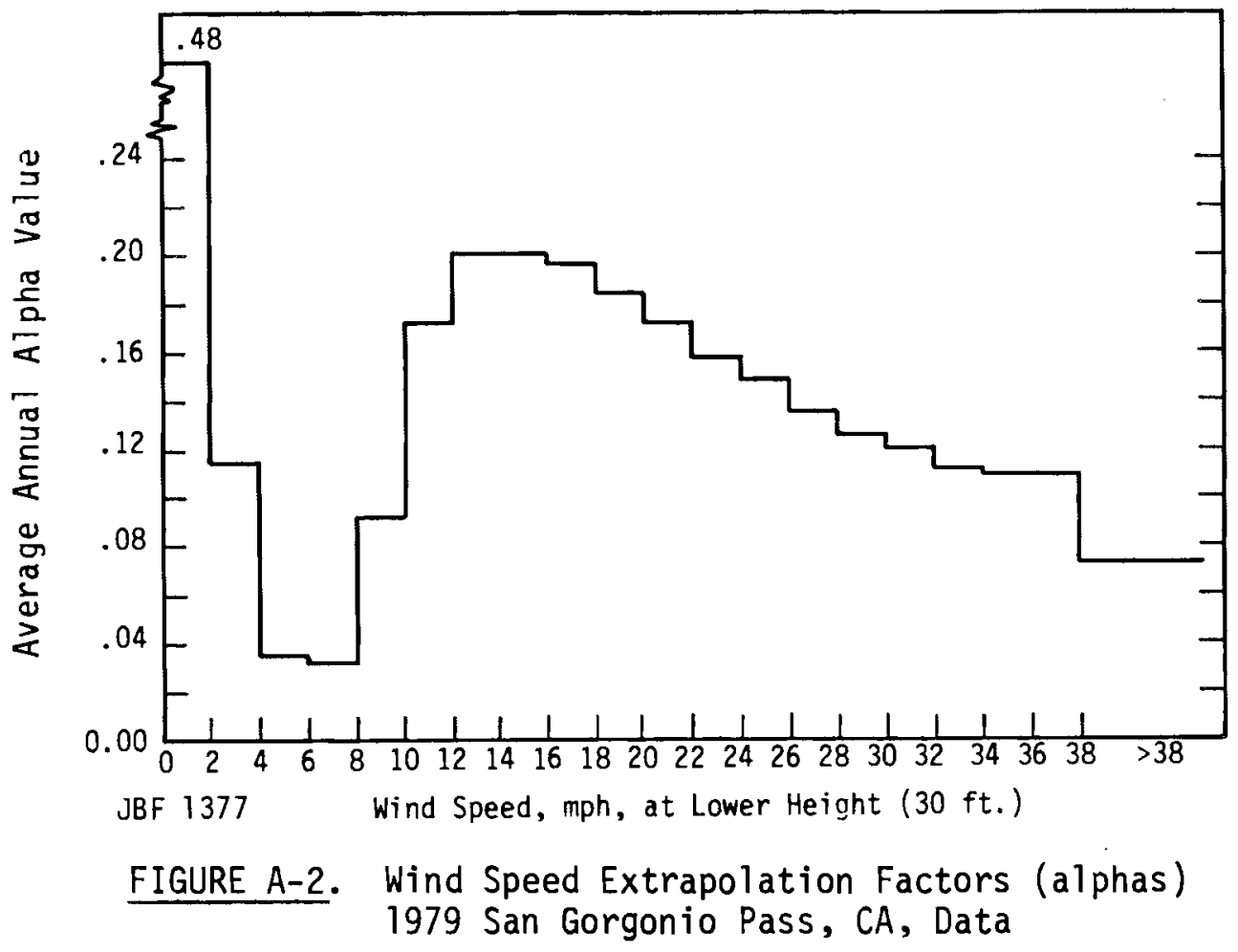

results are almost the same as calculated values of the Justus-Mikhail expression (Justus and Mikhail 1976) with a surface roughness length of 0.05 . The average alpha value was 0.168 .

There were 2082 missing observations at $30 \mathrm{ft}$ and 2411 at $150 \mathrm{ft}$, (or 0.8 and $0.9 \%$ of the total observations, respectively). In the rehabilitation process, $10 \%$ of the data were replaced with annual statistical averages due to observations missing simultaneously at both heights. Also, $3 \%$ of the data were estimated from the lower wind velocities and extrapolation factors, due to missing or anomalous data at the upper height. Figure A-3 presents the 150-ft August San Gorgonio wind speeds used in this study and includes about 16 days wind speed data calculated using the rehabilitation process. Note that the wind speeds calculated from the rehabilitation process were above the MOD-2's cut-in wind speed. As a result, the MOD-2 capacity factor calculated for August was slightly higher than might be expected from examination of the actual wind speed data available for the month. 


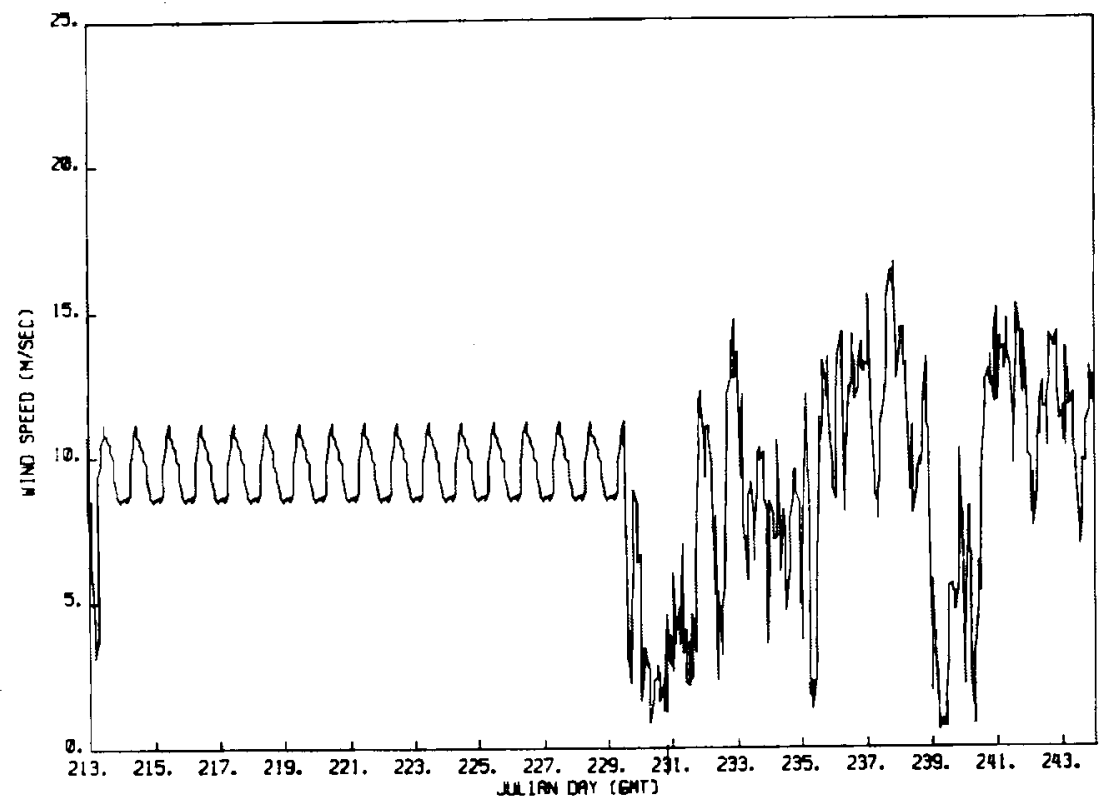

FIGURE A-3. San Gorgonio Observed and Rehabilitated Hourly Wind Speeds at $150 \mathrm{ft}$ - August

The annual average wind speed for the complete 1979 San Gorgonio wind year at MOD-2 hub height $(200 \mathrm{ft})$ was calculated to be $7.6 \mathrm{~m} / \mathrm{s}(17.2 \mathrm{mph})$. This compares with averages of $5.7 \mathrm{~m} / \mathrm{s}(12.8 \mathrm{mph})$ and $7.5 \mathrm{~m} / \mathrm{s}(16.8 \mathrm{mph})$ at $30 \mathrm{ft}$ and $150 \mathrm{ft}$ before data rehabilitation. The wind speed at $200 \mathrm{ft}$ would be about $5 \%$ greater than the wind speed at $150 \mathrm{ft}$ under average a conditions. However, due to the large amount of wind speeds 1 ess than $4.4 \mathrm{~m} / \mathrm{s}$ (10 mph) that had low extrapolation factors and to the anomalous data at low wind speeds, the wind speed difference between these heights was calculated to be on1y $2.5 \%$.

Figures A-4 and A-5 show the monthly and diurnal wind shapes for the complete San Gorgonio wind year using hourly average wind speeds. Monthly patterns show significant variations, with the peak months in the spring and summer and the low months in fall and winter. Averages for December and January are about $10 \mathrm{mph}$, well below the MOD-2 cut-in speed of $14 \mathrm{mph}$. The diurnal pattern is smooth, with a distinct peak in the late afternoon/early evening and a minimum in the late morning. 


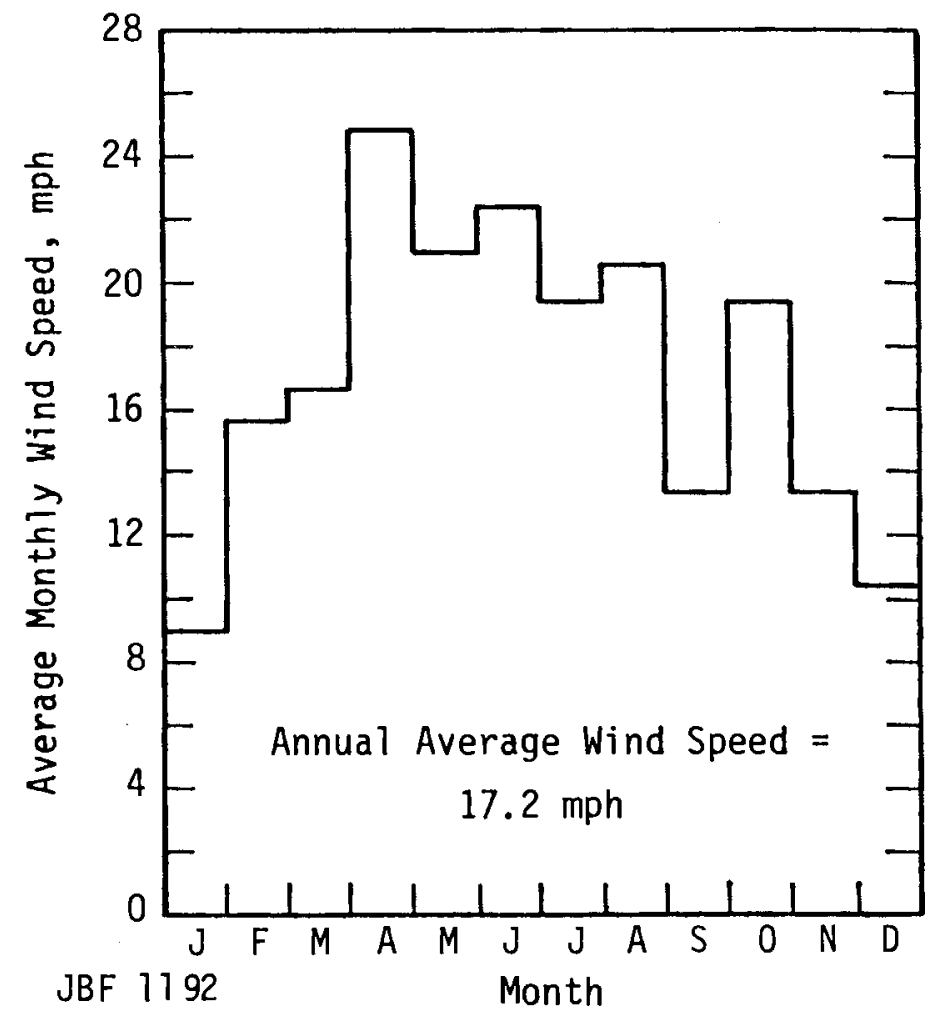

FIGURE A-4. Monthly Wind Pattern 1979 San Gorgonio Pass Data at $200 \mathrm{ft}$

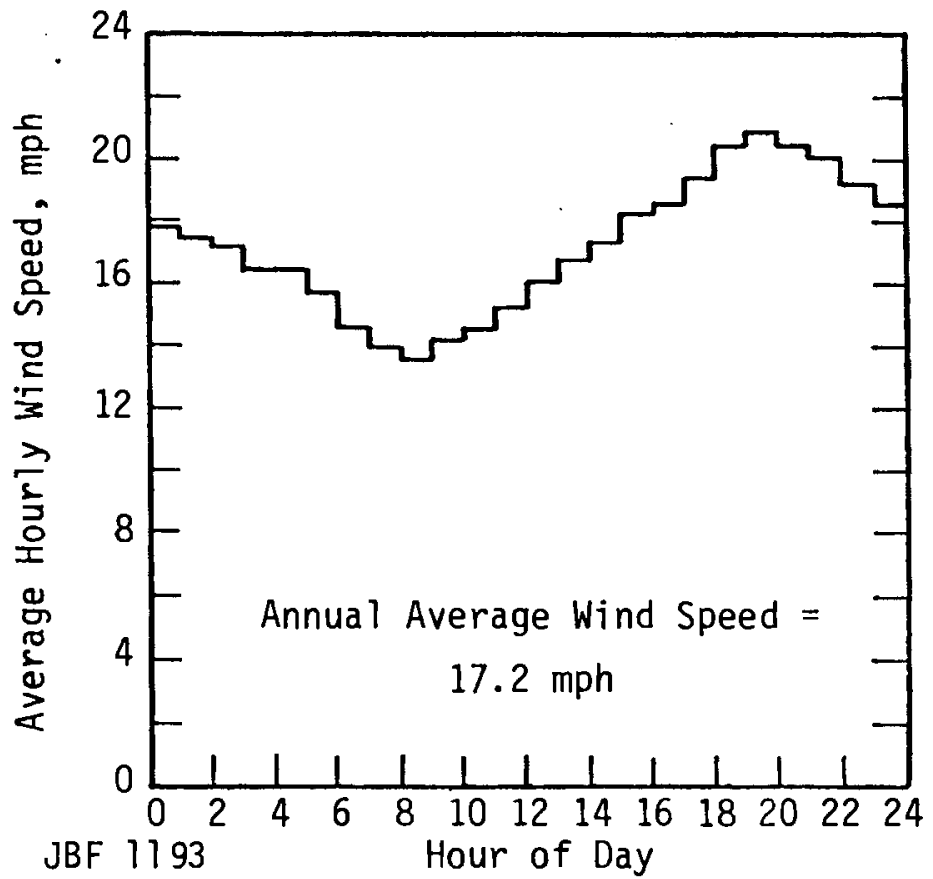

FIGURE A-5. Diurnal Wind Pattern 1979 San Gorgonio Pass Data at $200 \mathrm{ft}$ 
Wind duration curves for the San Gorgonio 2-min speeds are presented for 30, 150, and $200 \mathrm{ft}$ in Figure A-6. The 200-ft curve has some interesting implications relative to MOD-2 performance. These are:

- only $54 \%$ of the wind speed observations are above the machine's cut-in of $6.2 \mathrm{~m} / \mathrm{s}(14 \mathrm{mph})$,

- $21 \%$ are above its rated speed of approximately $12.5 \mathrm{~m} / \mathrm{s}$ (28 mph), and

- approximately $2 \%$ of the observed wind speeds are above the machine's cut-out speed of $20.1 \mathrm{~m} / \mathrm{s}$ (45 mph).

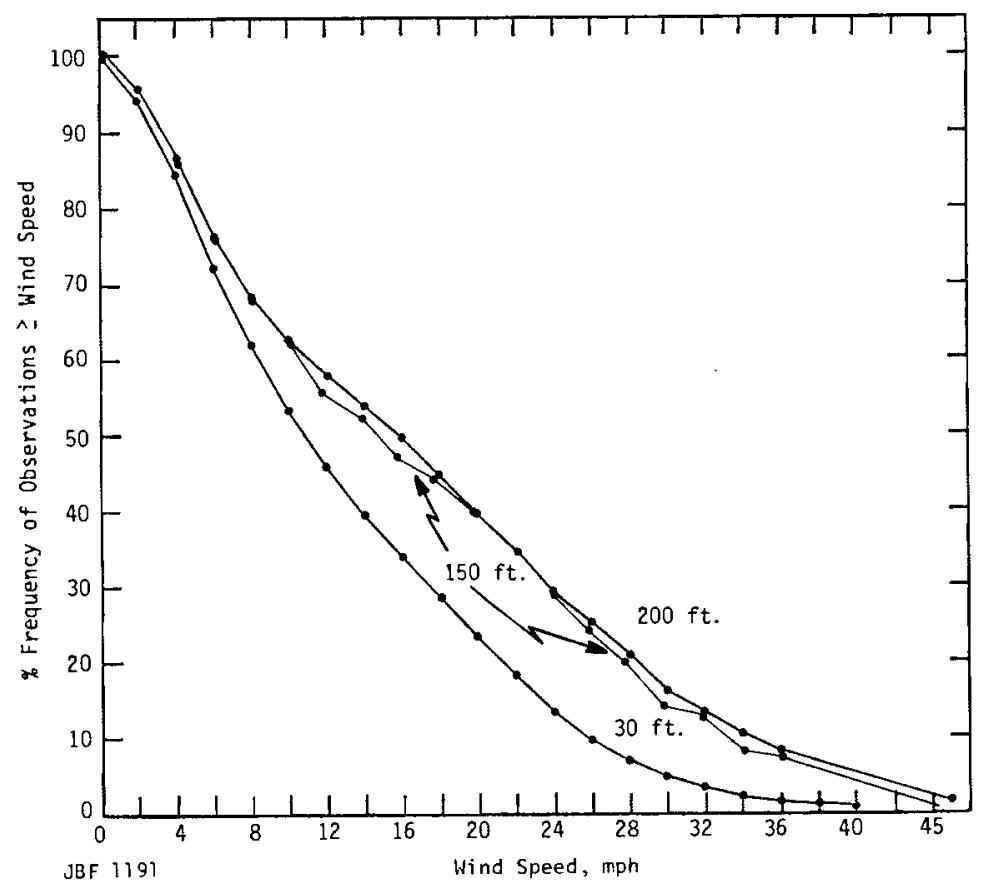

FIGURE A-6. Wind Duration Curve 1979 San Gorgonio Wind Data

In retrospect, for the purposes of this study the methods of rehabilitation employed were probably quite adequate though without doubt creating a minor bias in the energy production. It is recommended that for future studies requiring similar data rehabilitation, consideration be given to the use of shorter term mean winds, i.e., 3-4 days and the higher order moments of the wind speed spectra in specifying the data; this is to produce a more realistic 
variance spectrum. Further, were some measure of atmospheric stability available, it is believed that a significant portion of the anomalous data eliminated in this study would not have been. At San Gorgonio Pass at night in the cooler months, the atmosphere can be quite stable, therefore wind speeds near the surface can easily exceed those at hub height though, as noted, would most likely be relatively low in value.

\section{REFERENCES}

Justus, C. G. and Mikhail, A. 1976. "Height Variation of Wind Speed and Wind Distribution Statistics." Geophys. Res. Letters, 3:261-264. 


\section{APPENDIX B}

AIR DENSITY CORRECTION 
APPENDIX B

\section{AIR DENSITY CORRECTION}

An air density correction factor has been developed and incorporated into JBF wind energy conversion system (WECS) performance models. The air density correction includes the effects of elevation and air temperature. The correction is required to convert WECS performance data usually calculated at sea level density to the performance expected at the machine's elevation.

To correct for density, the actual site wind speed is converted to an equivalent or effective wind speed at the standard density. At standard density, the effective speed results in the same power as the actual speed at the actual density.

In mathematical terms, the density correction is described by equating available power at the two velocity and density points.

$$
\begin{aligned}
& P=(1 / 2 A) \rho_{A} V_{A}^{3} \\
& P=(1 / 2 A) \rho_{0} V_{E}^{3}
\end{aligned}
$$

where $P=$ power output

$A=$ rotor-swept area

$\rho_{A}=$ actual air density

$V_{A}=$ actual wind velocity

$\rho_{0}=$ standard air density

$V_{E}=$ equivalent or effective wind velocity.

Combining Equations (B-1) and (B-2) yields:

$$
\rho_{A} V_{A}^{3}=\rho_{0} V_{E}^{3}
$$

and

$$
V_{E}={\frac{\rho_{A}}{\rho_{0}}}^{1 / 3} V_{A} .
$$


The ratio of actual to standard density is defined by Justus (1978).

$$
\frac{\rho_{A}}{\rho_{0}}=e^{-Z / H}-(T-15) / 288 .
$$

where $Z$ = elevation, $m$ above mean sea level

$\mathrm{H}=8435 \mathrm{~m}$

$\mathrm{T}=$ air temperature, ${ }^{\circ} \mathrm{C}$

The wind turbine computer model is programmed to use temperature data as either hourly observations or monthly means. The speed adjustment methods for density correction provides similar results to a power adjustment method, where power is first computed for the actual windspeed and then multiplied by the value of Equation (B-5) for density correction.

Table B-1 presents a few calculations to compare the two methods. As expected, the most significant variation is around cut-in and rated speeds, since the velocity adjustment effectively modified these values.

TABLE B-1. Wind Power Calculations With Density Corrections (for MOD-2 Performance)

\begin{tabular}{|c|c|c|c|c|}
\hline$\rho_{A} / \rho_{0}$ & $V_{A} \mathrm{mph}$ & $V_{E}, \mathrm{mph}$ & $P(a), k W$ & $\mathrm{P}(\mathrm{b}), \mathrm{kW}$ \\
\hline 0.9 & 14.0 & 13.52 & 406 & 0 \\
\hline 0.9 & 14.2 & 14.00 & 385 & 406 \\
\hline 0.9 & 15.0 & 14.48 & 409 & 427 \\
\hline 0.9 & 25.0 & 24.14 & 1606 & 1609 \\
\hline 0.9 & 28.0 & 27.03 & 2250 & 2243 \\
\hline 0.9 & 29.0 & 28.00 & 2473 & 2500 \\
\hline 1.1 & 13.6 & 14.04 & 0 & 408 \\
\hline 1.1 & 27.0 & 27.87 & 2459 & 2450 \\
\hline
\end{tabular}

(a) Using power adjustment for density

(b) Using windspeed adjustment for density 
For $\rho_{A} / \rho_{0}=0.9$, cut-in "effectively" occurs at an actual velocity $=6.4 \mathrm{~m} / \mathrm{s}(14.5 \mathrm{mph})$. For $\rho_{A} / \rho=1.1$, "effective" cut-in is reduced to about $6.0 \mathrm{~m} / \mathrm{s}(13.6 \mathrm{mph})$. Similar shifts occur with rated and cut-out wind speeds.

In future studies using the time-dependent performance model, it is recommended that the power output curve for the machine be adjusted for air density rather than adjusting wind speeds. Because the anemometry controlling startup of the wind turbine is not sensitive to atmospheric density (a function of altitude and temperature primarily), correcting speeds for density would produce an artificially higher wind speed for machine cut-in and cut-out. The higher cut-in speed could potentially decrease the number of start-stop cycles and the number of aborted startups but would also result in increased downtime and reduced annual power production.

In this study the effects of applying the air density correction to wind speed were partially mitigated by the wind characteristics of the San Gorgonio site. Two distinct wind regimes exist at San Gorgonio, high gusty winds (well above the MOD-2 cut-in) and low windspeeds (more laminar and generally below MOD-2 cut-in). Furthermore, one regime tends to dominate for several successive hours before a transition takes place. Artificially reduced annual power production would also have been mitigated somewhat by the increased cut-out speed, which would allow more power to be produced during the frequent high wind episodes at San Gorgonio.

\section{REFERENCES}

Justus, C. G. 1978. Winds and Wind System Performance, Frankl in Institute Press, Philadelphia, Pennsylvania. 


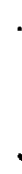

. 


\section{APPENDIX C}

UTILITY OPERATING PROCEDURES 
APPENDIX C

\section{UTILITY OPERATING PROCEDURES}

In the normal operating state, a utility must continuously adjust its generation to meet fluctuations in its load demand. In general, it takes a greater amount of time to start up a generator and synchronize it to the network than that necessary to follow load variations. Hence, a utility is required to make forecasts of its load requirements in order to assure a reliable supply of generating capacity capable of meeting and tracking its customer loads. The daily load forecasts are used to develop an equipment schedule (number and type of generators committed) that attempts to minimize the next day's cost of generation while providing reliable service. This is accomplished by making available for use a mix of equipment that has the lowest aggregated incremental costs.

This equipment schedule or unit commitment consists of two segments: synchronized generation and standby generation. Synchronized generation is defined as generation that is connected to the electric network and is capable of satisfying load requirements. Standby generation is generation that is available, on a short-term basis, but is not yet connected to the network (including all quick-start units such as diesel, pumped-hydro, and combustion turbines).

In general, a unit commitment schedule is designed to meet the following criteria:

1. At all times the synchronized generation capability must be such that the system is secure under any single contingency (failure of a single piece of equipment). On a number of systems, this is accomplished by having available synchronized generation (spinning reserves) equal to or greater than the capacity of the largest generating unit on line.

2. If at any time the above criterion is not matched due to the equipment failure or load forecast errors, then within a short time (typically 
$10 \min$ ), a portion of the standby generation must be capable of being synchronized in order to regain condition 1. (Interruptible loads are considered standby generation.)

3. Unit commitment must be made so that synchronized generation is available to follow load changes within reasonable limits, i.e., on an average, the area generation is able to match the area load exactly at least once in $10 \mathrm{~min}$, also the mismatch should never cause the system frequency to deviate beyond certain specified limits (normally $\pm 0.5 \mathrm{~Hz}$ ).

This implies that the unit commitment must take into account potential errors in daily load forecasting and should also take into account predicted shortterm (10 min) load rampings. (Load ramping predictions are based upon the past experience with the load fluctuations.) Because not all conventional generating units are capable of cycling (following load changes), the unit commitment schedule must take into consideration both economics of dispatch and equipment operational characteristics.

Further reading on utility operating procedures:

Miller, Robert H. 1970. Power System Operation. McGraw-Hill, New York, New York. 
APPENDIX D

LADWP LOADS 


\section{APPENDIX D}

\section{LADWP LOADS}

1995 estimated load profiles for a typical day and a typical week in October and July are shown in Figures $D-1$ and $D-2$. These load profiles have a similar shape but differ in the magnitude of their respective peaks. The week in July contains LADWP's peak hourly load, and is characterized by a cumulative weekly energy consumption of $600 \mathrm{GW}$ compared to the $545 \mathrm{GW}$ obtained for the week in October.

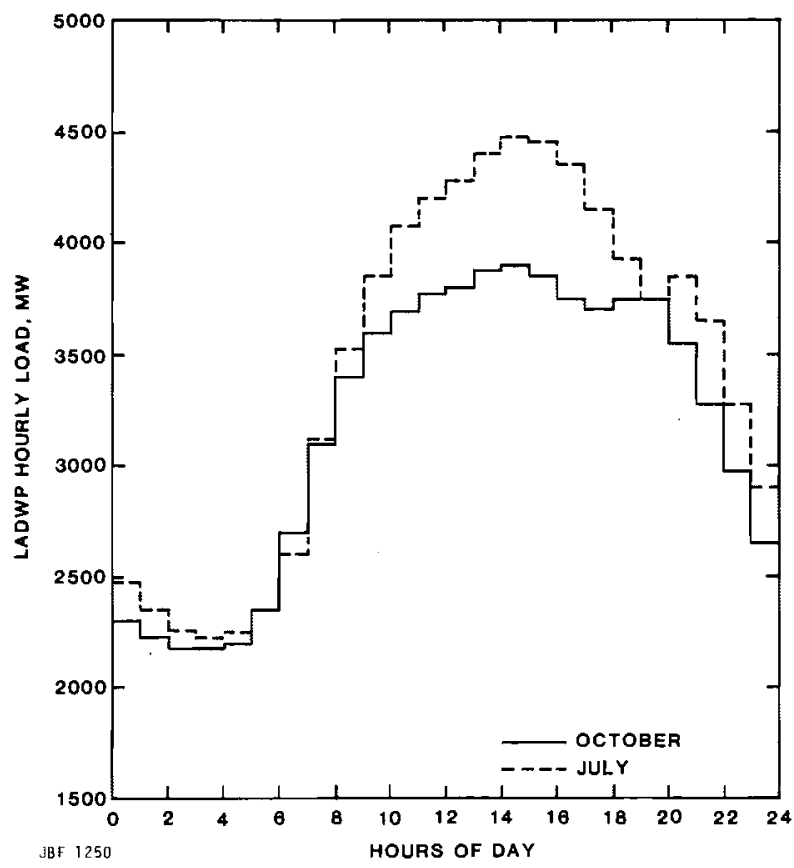

FIGURE D-1. 1995 Estimated LADWP Hourly Load Profile 


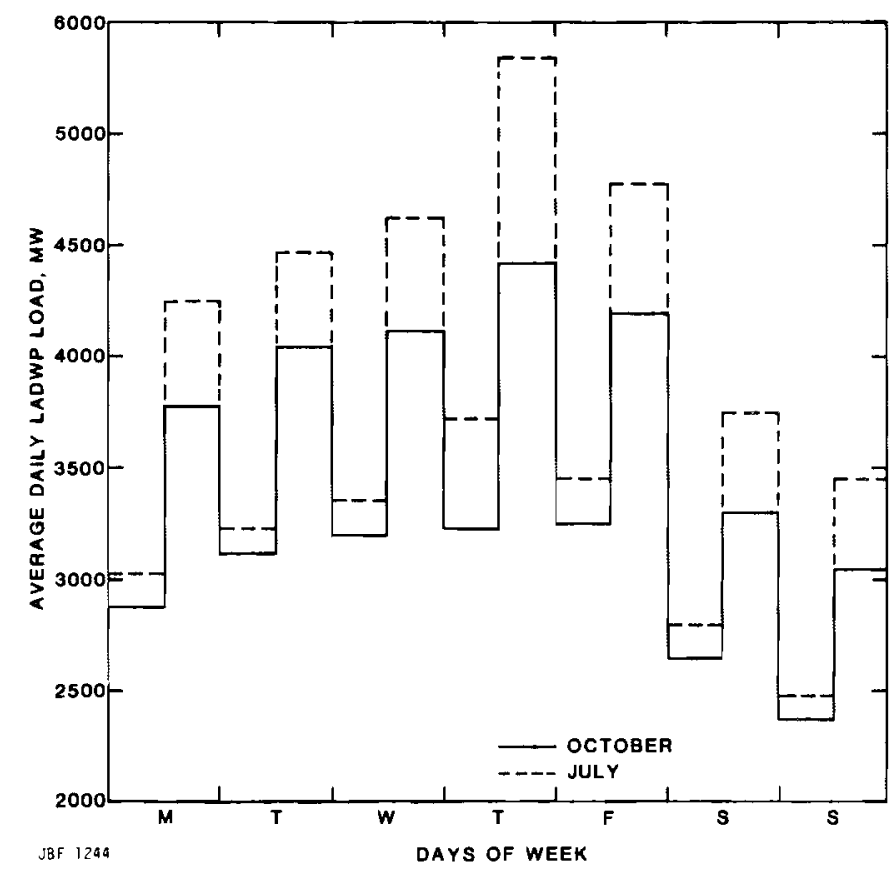

FIGURE D-2. 1995 Estimated Average Daily Load Profile 


\section{DISTRIBUTION}

No. of

Copies

\section{OFFSITE}

D. Ancona

Department of Energy

Wind Energy Technology Division

1000 Independence Avenue

Forrestal Building, Room 5F059

Washington, DC 20585

C. I. Aspliden

Battelle Memorial Institute

Washington Operations Office

2030 M Street N.W.

Washington, DC 20036

S. D. Berwager

Department of Energy

Wind Energy Technology Division

1000 Independence Avenue

Forrestal Building, Room 5F059

Washington, DC 20585

L. V. Divone

Department of Energy

Wind Energy Technology Division

1000 Independence Avenue

Forrestal Building, Room $5 F 059$

Washington, DC 20585

W. C. Reddick

Department of Energy

Wind Energy Technology Division

1000 Independence Avenue

Forrestal Building

Washington, DC 20585

G. P. Tennyson

Department of Energy

Albuquerque Operations Office P.0. Box 5400

Albuquerque, NM 87110

27 DOE Technical Information Center
No. of

Copies

2 Peter Lissaman/Andrew Zalay

Aerovi ronment, Inc.

145 Vista Avenue

Pasadena, CA 91107

W. A. Vachon

Arthur D. Little, Inc.

20 Acorn Park

Cambridge, MA 02140

E. J. McGlinn, Corporate Director

The Bendix Corporation

Bendix Center

Southfield, MI 48037

Nicholas Butler

Bonneville Power Administration

P.0. Box 3261-EIC

Portland, OR 97208

Don Nielson

Boeing Engineering and

Construction Co.

P.0. Box 3707 , MS-9A-65

Seattle, WA 98124

Joe Hennessy

California Wind Energy Program

1111 Howe Avenue, Mai1 Stop 66

Sacramento, CA 95825

S. J. Hightower

Bureau of Reclamation

Denver Federal Center

Building 67, Code 254

Denver, CO 80225

2 Dr. Edgar DeMeo/Frank Goodman, Jr. Electric Power Research Institute 3412 Hillview Avenue

Palo Alto, CA 94303 
No. of

Copies

2 J. M. Kos/Eugene Di Valentin

Hamilton Standard

Bradley Field Road

Windsor Locks, CT 06096

5 M. K. Goldenblatt

JBF Scientific Corporation

2 Jewel Drive

Wilmington, MA 01887

E. E. Johanson

JBF Scientific Corporation

2 Jewel Drive

Wilmington, MA 01887

Gerald Park

Department of Electrical Engineering Michigan State University

East Lansing, MI 48824

2 Tim R. Richards/Dave Spera

NASA/Lewis Research Center

21000 Brookpark Road

Cleveland, $\mathrm{OH} \quad 44135$

Phillip French

NASA Scientific and Technical Information Facility

P.0. Box 8757

Bal timore/Washington International Airport

Baltimore, MD 21240

Peter M. Moretti

Oklahoma State University

Mechanical and Aerospace Engineering

Engineering North 218

Stillwater, OK 74074

R. L. Simon

Pacific Gas and Electric

215 Market Street

San Francisco, CA 94106
No. of

Copies

Carl D. Stultz

Pacific Power

920 S.W. 6th Avenue

Portland, OR 97204

Terry J. Healy/C. Hansen

Rockwell International

Rocky Flats Plant

P.0. Box 464

Golden, CO 80401

E. G. Kadlec

Sandia Labs 4715

Box 5800

Albuquerque, NM 87165

Bruce Bailey

Atmospheric Sciences Research Center

State University of New York at Albany

Albany, NY 12222

Sherman M. Chan

Systems Control, Inc.

1801 Page Mill Road

P.0. Box 10025

Palo Alto, CA 94303

Billy Owens

Tennessee Valley Authority

320 Credit Union Building

715 Market Street

Chattanooga, TN 37401

Farrell Smith Seiler

Wind Energy Report

Box 14 - 104 S. Village Avenue

Rockville Centre, NY 11571

Henry W. Zaininger

Zaininger Engineering Co.

3408 Vance Court

San Jose, CA 95132 
No. of

Copies

Per Lundsager

Risø National Laboratory

P.0. Box 49

DK-4000 Roskilde

DENMARK

2 Ors. Werner Dub/Heinz Pape

Forschungsprojekt Windenergie

Un iversitätsstrasse 31

D-8400 Regensburg

GERMANY

Dr. Neil Cherry

Lincoln College

Canterbury

NEW ZEALAND

\section{ONSITE}

1 DOE Richland Operations Office

H. E. Ransom
No. of

Copies

\section{Pacific Northwest Laboratory}

W. R. Barchet

J. W. Buck

J. R. Connell

J. C. Doran

K. Drumheller

C. E. Elderkin

D. L. Elliott

R. L. George

D. L. Hadley

A. H. Miller

E. L. Owczarski

D. C. Powe11

J. V. Ramsdell

D. S. Renné

H. L. Wegley

L. L. Wendel1

R. K. Woodruff

Technical Information - Library (5)

Publishing Coordination (2)

WCPE Program Office (15) 


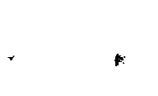

. 